'Without the Captain': Iuliu Maniu and the Romanian Legionary Movement after the Death of Corneliu Zelea Codreanu

Author(s): Rebecca Haynes

Source: The Slavonic and East European Review, Vol. 97, No. 2 (April 2019), pp. 299-341

Published by: the Modern Humanities Research Association and University College London, School of Slavonic and East European Studies

Stable URL: https://www.jstor.org/stable/10.5699/slaveasteurorev2.97.2.0299

JSTOR is a not-for-profit service that helps scholars, researchers, and students discover, use, and build upon a wide range of content in a trusted digital archive. We use information technology and tools to increase productivity and facilitate new forms of scholarship. For more information about JSTOR, please contact support@jstor.org.

Your use of the JSTOR archive indicates your acceptance of the Terms \& Conditions of Use, available at https://about.jstor.org/terms 


\title{
'Without the Captain': Iuliu Maniu and the Romanian Legionary Movement after the Death of Corneliu Zelea Codreanu
}

\author{
REBECCA HAYNES
}

\section{Introduction}

A previous article in this journal explored the links between Corneliu Zelea Codreanu, the founder and leader of the Romanian Legionary movement (also known as the Iron Guard), and Iuliu Maniu, president of the National Peasant Party. We argued there that the 1937 electoral pact was no mere short-term marriage of convenience but was based upon Maniu and Codreanu's common desire to overturn King Carol II's increasingly dictatorial regime and their shared values of Romanian nationalism. ${ }^{2}$ Following Codreanu's murder by Carol's regime in November 1938, Maniu condemned the royal government and continued to maintain links with Legionaries still at liberty, especially in his native Transylvania where he gave his followers permission to enrol Legionaries into the National Peasant Party. ${ }^{3}$ Codreanu's pro-Axis position made for excellent propaganda against Maniu during his trial by the Communists in 1947. Maniu's defence of Codreanu during his trial in May 1938 to the effect that 'I made the pact of non-aggression for the elections [of 1937] because I

Rebecca Haynes is Senior Lecturer in Romanian History at UCL SSEES.

1 Constantin Papanace, Fără Căpitan: conducerea în a doua prigoană, Bucharest, 1997, is a history of the movement during Codreanu's imprisonment. Following Codreanu's murder, and despite rumours that he was still alive, Papanace was forced to admit that the future for every Legionary was one 'fără Căpitan', i.e. without the Captain (as Codreanu was known to his followers).

${ }^{2}$ See Rebecca Ann Haynes, 'Reluctant Allies? Iuliu Maniu and Corneliu Zelea Codreanu against King Carol II of Romania', Slavonic and East European Review, 85, 2007, 1, pp. 105-34.

3 Ioan Hudița, Jurnal politic (with an introduction by Dan Berindei), 3 vols, Bucharest, 2002-04, vol. 2 (16 septembrie 1938 - 30 aprilie 1939), Bucharest, 2003, 2 December 1938, pp. 121-22. Ioan Hudița was secretary-general of the National Peasant Party in the Regat (or Old Kingdom).

Slavonic and East European Review, 97, 2, 2019 
was convinced of the sincerity and honesty of the accused Codreanu' was constantly quoted against Maniu by the prosecution. ${ }^{4}$ During sentencing, Maniu was declared to have been fully cognisant that the Legion was a German 'fifth column' during the period of his collaboration with Codreanu. Maniu and the National Peasant Party had, according to the prosecution, openly declared themselves 'in favour of the fascist ideology and the whole criminal policies of Hitler and Mussolini'.

In the post-Communist era Maniu is widely regarded as interwar Romania's leading exponent of democracy and constitutionalism. Consequently, Maniu's association with a self-confessed admirer of Adolf Hitler has been a difficult area for historical exploration. There is little in the secondary literature regarding Maniu's links with the Legion beyond brief discussions of the 1937 electoral pact. ${ }^{6}$ The Legion, however, continued to be important in Romanian domestic politics after Codreanu's death in 1938, as well as being a factor in Romania's relations with Nazi Germany. Maniu recognized that the Legion was, therefore, an unavoidable player in Romanian politics. ${ }^{7}$ Consequently, contacts between Maniu and the movement continued to be a necessity, as they had been in 1937.

4 Marcel-Dumitru Cuică, Procesul lui Iuliu Maniu. Documente procesului conducătorilor Partidului Național Țărănesc, 3 vols, Bucharest, 2001, vol. 2, part 1, doc. 2, pp. 10-69, (p. 49); ibid., vol. 2, part 2, doc. 88, pp. 131-50 (p. 145); ibid., vol. 3, doc. 1, pp. 5-379 (p. 176). The politician, and supporter of the royal dictatorship, Constantin Argetoianu, also regarded Codreanu as sincere and honest. See Stelian Neagoe (ed.), Constantin Argetoianu, Însemnări zilnice, 10 vols, Bucharest, 1998-2009 (hereafter, Argetoianu), vol. 2, p. 222, 17 May 1937. For a recent biography of Codreanu which stresses his religious mysticism, see Oliver Jens Schmitt, Căpitan Codreanu. Aufstieg und Fall des rumänischen Faschistenführers, Vienna, 2016.

5 Cuică, Procesul lui Iuliu Maniu, vol. 3, doc 1, pp. 5-379 (p. 176). For condemnation of Maniu in Communist-era historiography, see, for example, Lucrețiu Patraşcanu, Sub trei dictaturi, Bucharest, 1970, p. 106. For the Legion's lack of credentials as a German fifth column, see Haynes, 'Reluctant Allies?', pp. 126-27.

6 For biographies of Maniu and information about the 1937 pact, see Apostol Stan, Iuliu Maniu. Naționalism şi democrație. Biografia unuii mare român, Bucharest, 1997, pp. 318-25; Ioan Scurtu, Iuliu Maniu. Activitatea politică, Bucharest, 1995, pp. 85-94; Cicerone Ionițoiu, Viața politică şi procesul Iuliu Maniu, Bucharest, 1997, pp. 126-34. For a more detailed account of the 1937 electoral pact and its aftermath, see Petre Turlea, Carol al II-lea şi Iuliu Maniu, Bucharest, 2013, pp. 258-62, 282-97, 339-49. Mihai Pelin, Iluziile lui Iuliu Maniu, Bucharest, 2000, relates to Maniu's activities between 1940 and 1943, including brief indications of his attitudes towards the Legion, and is critical of Maniu. Constantin Petculescu, Mişcarea legionară. Mit şi realitate, Bucharest, 1997, provides information regarding Legionary links with the National Peasant Party from 1944.

7 For the growth in Legionary electoral support in the 1930s, see Armin Heinen, 'WahlMaschine. Die Legion "Erzengel Michael”, die Wahlen 1931-1937 und die Integrationskrise des rumänischen Staates', in Armin Heinen and Oliver Jens Schmitt (eds), Inszenierte Gegenmacht von rechts: Die 'Legion Erzengel Michael' in Rumänien 1918-1938, Munich, 2013, pp. 130-154. 
Maniu sought where he could to harness Legionary energies in a constructive direction (especially for the defence of Transylvania against Hungarian revisionism), and to divert its members from possible collaboration with King Carol. Maniu remained the principal opponent of the royal dictatorship amongst politicians from the traditional parties and tenaciously sought Carol's abdication. ${ }^{8}$ For their part, some Legionaries regarded Maniu as their ally against the king, under whose auspices their leader had been murdered, and were drawn to Maniu due to his previous friendship with Codreanu. For Transylvanian Legionaries collaboration with Maniu was also based upon common Transylvanian origins and Maniu's high standing in the province. Indeed, Maniu was regarded, and regarded himself, as the primary representative of Transylvania within Greater Romania. Given the centrality of Transylvania within Romanian national consciousness, Maniu's origins and position within the province served to give him a symbolic significance within Romanian politics. ${ }^{9}$ As the Transylvanian Legionary Horațiu Comaniciu writes in his memoirs, 'Maniu was a myth [...] in Transylvania especially the masses remained constantly faithful to him.' ${ }^{10}$

The Legion had long portrayed itself as being in opposition to the 'decadent' and 'corrupt' Romanian political class. Certain Legionaries were, nevertheless, prepared to collaborate with the austere Maniu who had a reputation for incorruptibility and who himself regarded most of the politicians of the Regat (or Old Kingdom) as corrupt. ${ }^{11}$ At all times Maniu,

8 Maniu began a close collaboration with Constantin (Dinu) I. C. Brătianu, leader of the National Liberal Party, after the declaration of the royal dictatorship in February 1938 in order to coordinate common action against the regime. It was Maniu who, however, played 'the part of first fiddle': Ioan Scurtu, Istoria Partidului Național Țărănesc, Bucharest, 1994, (hereafter, Scurtu, Istoria PNȚ), p. 335.

9 For the significance of Transylvania within interwar Romania, see Holly Case, Between States: The Transylvanian Question and the European Idea during World War II, Stanford, CA, 2009, p. 10. For Maniu's view of himself as the representative of Transylvania within interwar Romania, see Gábor Egry, 'Crowding Out: Experiences of Difference, Discourses of Identity and Political Mobilization in Interwar Transylvania', Studia Universitatis Cibiniensis. Series Historica, 9, 2012, pp. 161-82 (esp. pp. 171, 181-82). For Maniu's distinguished Transylvanian Uniate ancestry, see Mihai Sorin Rădulescu, 'Despre genealogia lui Iuliu Maniu', in Niculae Paraschiv (ed.), Iuliu Maniu în fața istoriei, Bucharest, 1993, pp. 14-20.

${ }^{10}$ Horatiu Comaniciu, In lupta neamului (Amintiri), Consiliul National Roman [sic], no place of publication, no date, p. 22.

${ }^{11}$ For the Legion's opposition to the established political class, see, for example, Roland Clark, Holy Legionary Youth: Fascist Activism in Interwar Romania, Ithaca, NY and London, 2015, p. 215; Radu Harald Dinu, Faschismus, Religion und Gewalt in Südosteuropa. Die Legion Erzengel Michael und die Ustaša im historischen Vergleich, Wiesbaden, 2013, p. 86; Rebecca Haynes, 'Work Camps, Commerce, and the Education of the "New Man" 
however, expected any full-scale collaboration between Legionaries and the National Peasant Party to be based upon an acceptance of democracy and a pro-Western foreign policy. Horia Sima and his supporters' rejection of democracy and adherence to antisemitic violence and a pro-Axis foreign policy were ultimately incompatible with Maniu's values. ${ }^{12}$

This article will chart Maniu's links with the Legion when it was under the contested leadership of Horia Sima during the period of King Carol II's royal dictatorship and the subsequent National Legionary State. Relations between Maniu and the Legion took place within the context of major territorial revisionist demands upon Romania, which led to calls for autonomy amongst Transylvanians, as well as the outbreak of the Second World War, Romania's adherence to the Axis, and the creation and abolition of the National Legionary State. This discussion draws upon unpublished primary sources, including documents from the National Archives in Bucharest (former State Archives) and the archives of the German Foreign Ministry in Berlin, as well as published documents and memoirs. The limitations of these sources should be noted: Romanian police reports from the period were frequently based upon hearsay and are therefore not always reliable; names of specific Legionaries with whom Maniu had contact, even in Transylvania, are rarely given, and the outcomes of discussions between Maniu or his colleagues and Legionaries are not always easy to ascertain. There is tantalizing evidence in the documents of Maniu's activities in Transylvania at the time of the August 1940 Vienna Award, some of which were co-ordinated with the Legionaries, but these sources do not reveal Maniu's possible role in the demonstrations of 3-6 September which forced the abdication of King Carol. Nevertheless, despite their short-comings, the sources overall provide compelling evidence of the continuation of Maniu's contacts with the Legionary movement after Codreanu's death.

Maniu and his close colleagues and supporters are regularly described as 'manişti' in the archival sources. In view of this, and since it serves as a useful shorthand, Maniu's followers will be rendered as 'Manists' where appropriate in this article.

in the Romanian Legionary Movement', The Historical Journal, 51, 2008, 4, pp. 943-67 (esp. pp. 943-54). For Maniu and the National Peasant Party's view of Regat politicians as corrupt, see Egry, 'Crowding Out', esp. p. 171. According to Henry L. Roberts, Maniu's 'cold incorruptibility' was 'in the sharpest possible contrast to the laxness and opportunism of Rumanian public life'. Roberts, Rumania: Political Problems of an Agrarian State, New Haven, CT and London, 1951, p. 135.

${ }^{12}$ For Maniu's objections to these aspects of Legionary ideology under Codreanu, see Haynes, 'Reluctant Allies?', p. 114. 


\section{The ascent of Horia Sima}

Corneliu Codreanu's murder by the royal regime in November 1938 led to turmoil within the outlawed Legionary movement, since Legionaries still at liberty were unsure how to proceed without their leader. The Romanian ministry of the interior believed, however, that Codreanu had recommended before his death that his followers should 'join with Maniu's action' against the royal regime. ${ }^{13}$ According to the head of military intelligence, Eugen Cristescu, giving evidence at his post-war trial, Codreanu's will had designated thirteen potential successors as leader of the movement. The list was headed by Gheorghe Clime, president of 'All for the Country' (Totul pentru Țară, the political wing of the movement) and head of the Legionary Workers' Corp (Corpul Muncitoresc Legionar). Horia Sima was to succeed to the leadership only if all thirteen successors should fall. Cristescu confirmed that if the movement found itself without a leader, or facing particular difficulties, Codreanu had commanded his Legionaries to follow Maniu. ${ }^{14}$ With the imprisonment of so many senior Legionaries in 1938, including Clime, a role for Maniu as leader or adviser to the movement seemed a distinct possibility. In keeping with this, on 9 December 1938 the security police reported that the Manists were distributing Codreanu's circular of January 1938 in which Codreanu had praised Maniu. The Manists hoped thereby to 'show the Legionaries that Iuliu Maniu is Codreanu's political successor. ${ }^{15}$

It was Horia Sima who, however, was to emerge as Codreanu's successor rather than Iuliu Maniu. Sima had established a power base in the Banat in the early 1930 s and in 1935 Codreanu elevated Sima to Legionary Commander and chief of X Region Timişoara in the Banat. The police in the Banat regarded Sima as an able leader and, presciently as it emerged, considered the Legionary organization created by him as potentially dangerous to public order. ${ }^{16}$ In 1935 Sima began collaborating with Nicolae

${ }^{13}$ Arhivele Naţionale Istorice Centrale, Bucharest, (hereafter, ANIC), Fond Ministerul de Interne, Diverse, dosar nr 26/1938, f. 114, unmarked note dated 4 December 1938.

${ }^{14}$ Cristescu had worked for the security police (Siguranța) for fourteen years, followed by six years in the ministry of the interior before becoming head of the military intelligence service (Serviciul Special de Informații, or SSI) in November 1940. He was anti-Legionary and had an informant within the movement. Cristian Troncotă (ed.), Eugen Cristescu: asul Serviciilor Secrete românești - memorii, mărturii, documente -, Bucharest, 1994, doc. 11, pp. 312-25 (pp. 316-17); doc. 15, pp. 342-75 (p. 371).

15 Vasile Arimia, Ion Ardeleanu, Alexandru Cebuc (eds), Istoria Partidului Național Țărănesc: documente 1926-1947, Bucharest, 1994, doc. 40, p. 188, 9 December 1938, Note of the security police referring to links between the National Peasant Party and the Guardist movement after the assassination of Corneliu Codreanu.

${ }^{16}$ Ilarion Țiu, Mişcarea Legionară după Corneliu Codreanu, 2 vols, Bucharest, 2007, vol. 
Petraşcu, leader for Sibiu county, and was thus able to forge links with the Transylvanian Legionary membership. ${ }^{17}$ Sima's work in the provinces meant that he was a largely unknown figure in Bucharest ${ }^{18}$ but this, together with his strong provincial following, was to work in his favour in his bid to take control of the movement.

The acts of terrorism organized by Sima in Transylvania in November 1938 may well have contributed to King Carol's decision to eliminate Codreanu. ${ }^{19}$ The blame for Codreanu's death has thus been lain at Sima's door by his adversaries, especially given that following his imprisonment in May 1938 Codreanu had called for calm in the belief that violence would lead to his death. ${ }^{20}$ A report drawn up by the police during Sima's interrogation in May 1940 concluded that Sima ignored Codreanu's plea for non-violence and carried out acts of terrorism with the specific aim of decapitating the movement and usurping the leadership. ${ }^{21}$ Certainly, Sima's use of violence and terror became an apparent dividing line between members of the Legionary movement: the so-called codrenisti (who followed Codreanu's non-violent line after his death and tended to view Maniu favourably) and Sima's followers, the simişti, for whom Maniu was a more marginal figure. ${ }^{22}$

During the summer of 1938 Sima, then in Bucharest, had became part of the so-called Comandamentul de prigoană (lit. Command of Persecution, hereafter, the Command), which included Nicolae Petraşcu, with whom Sima was already collaborating in Transylvania. It was Sima and Petraşcu

1, Dictatura regală (februarie 1938-septembrie 1940): mecanismele schimbului de generație, p. 71.

17 Ibid., p. 87. In 1934 Cluj, the Transylvanian capital, had the highest number of Legionary 'nests' in the country at 196. Dragoş Zamfirescu, Legiunea Arhanghelul Mihail: de la mit la realitate, Bucharest, 1997, p. 176.

18 Papanace, Fără Căpitan, p. 59.

19 For the fourteen, largely antisemitic, incidents carried out in Transylvania in November 1938 under Sima's auspices, see Dana Honciuc-Beldiman (ed.), Dosar Horia Sima (1940-1946), Bucharest, 2007, doc. 1, 19 May 1940, Note of the Detective Corps regarding the evolution of the Legionary movement in the period 1938-1940 and the evaluation of the possibilities of subordinating it to Carolist politics, pp. 5-52 (p. 17).

${ }^{20}$ Şerban Milcoveanu, Horia Sima altceva decât Corneliu Codreanu, 2 vols, Bucharest, 1996, vol. 1, pp. 36-42.

${ }^{21}$ Honciuc-Beldiman (ed.), Dosar Horia Sima, doc. 1, 19 May 1940, pp. 5-52 (pp. 18-19).

${ }^{22}$ These categories were not clear cut and Legionaries often moved between the two camps. Radu Mironovici, for example, was a founder-member of the Legion and ultimately emerged as a member of the moderate codrenişti wing of the movement. He nevertheless accepted Sima's leadership in 1940 and was briefly police prefect of Bucharest during the National Legionary State. Constantin Papanace collaborated with Sima between 1938 and 1940 and was subsecretary of state at the ministry of finance during the National Legionary State after which he broke with Sima and joined the codrenişti. 
who proved to be the most active amongst the members of the Command in reorganizing the Legion in Bucharest as well as in the provinces. Sima quickly became invaluable due to his dynamism and knowledge of the situation on the ground. Nevertheless, the increasing violence of the Legionary movement was not entirely Sima's doing but was also a product of the radicalization of the Legionaries during this era of repression by the royal government. ${ }^{23}$ Moreover, the disorder which erupted in Transylvania in November 1938 was not all fomented by Sima. According to the Spanish minister in Bucharest, this was also due to a protest movement which was led by Maniu and had 'autonomist nuances'. ${ }^{24}$ This was an indication that Maniu and his Transylvanian supporters might demand autonomy for Transylvania as a means of escaping from the misrule of the royal dictatorship.

Despite Sima's strong network in the Banat and Transylvania, it is unclear what links he had with Iuliu Maniu or other members of the National Peasant Party at this point. During his interrogation by the Romanian security police in May 1940, Sima revealed that he had maintained the exchange of information begun by Codreanu and Maniu at the time of the 1937 electoral pact which had continued uninterrupted until Codreanu's arrest. When exactly Sima renewed this contact is unknown, but he confirmed to his interrogators that it was conducted through the lawyer Horia Cosmovici who presented a report to Maniu at each meeting and received in exchange information regarding the possible intentions of King Carol in internal politics. ${ }^{25}$ It seems highly unlikely, however, that there would have been any coordination between the two men in November 1938 since Maniu categorically rejected Legionary antisemitic violence. ${ }^{26}$

${ }^{23}$ For the radicalization of the Legion after Codreanu's death and Sima's consolidation of power, see Țiu, Mişcarea Legionară, vol. 1, pp. 63-88.

${ }^{24}$ Francisco Veiga, (trans. Marian Ștefănescu) Istoria Gărzii de Fier 1919-1941: mistica ultranaționalismului, Bucharest, 1993, p. 258. The minister was reporting to Madrid on 25 November 1938.

${ }^{25}$ Honciuc-Beldiman (ed.), Dosar Horia Sima, doc. 12, 25 May 1940, Note of the Detective Corps regarding the interrogation of Horia Sima, pp. 71-81 (pp. 74-75). Horia Cosmovici took part in the 1937 electoral campaign on behalf of Totul pentru Țară and led an acerbic campaign against the king.

${ }^{26}$ Constantin Papanace confirms that Maniu's action in Transylvania was independent of that of the Legionaries. Papanace, Fără Căpitan, p. 120. 


\section{Maniu and the Legionaries against the National Renaissance Front}

In February 1939, Sima, together with other Legionaries, fled to Germany after a period of hiding in the Banat. ${ }^{27}$ Despite Sima's disappearance, German and Italian journalists based in Bucharest had reported in late December 1938 that the Legion in Romania planned to restart their activities in the New Year 'in part by supporting Iuliu Maniu's action of combating the present regime legally [...] and on the other hand by carrying out isolated acts of terrorism'. Significantly, the Legionaries were also prepared to use 'the threat of Transylvanian autonomy' in their fight against the king. ${ }^{28}$

It was in this context that Maniu and his colleague Mihai Popovici drew up a lengthy memorandum for King Carol on 15 December 1938. The memo enumerated the many shortcomings of successive Romanian governments in relation to Transylvania and the Banat, including the destruction of the provinces' political life. The royal dictatorship's centralist system meant that Transylvania and the Banat were effectively treated like 'conquered provinces', despite the fact they had freely joined Romania after the Great War. Evidence of the 'occupation' of these provinces was reflected in the fact that all county prefects in Transylvania and the Banat were military colonels from the Regat. The twenty years since the declaration of union with the Regat at Alba Iulia in 1918 had thus been nothing short of 'a complete disaster' for Transylvania and the Banat. The authors of the memo demanded 'a radical change of regime' with a return to parliamentary government. ${ }^{29}$

To compound Carol's domestic problems, his relations with Nazi Germany took a turn for the worse in late 1938 due to Hitler's furious reaction to the news of Codreanu's murder. ${ }^{30}$ Placating German anger might have been one of the reasons for the creation of the Frontul Renaşterii Naționale (hereafter, the FRN; the National Renaissance Front) on 16 December 1938. The FRN was the brain-child of Carol's minister of the

27 Țiu, Mişcarea Legionară, vol. 1, p. 115.

28 ANIC, Fond Ministerul de Interne, Diverse, dosar nr 26/1938, f. 265, unmarked note dated 22 December 1938.

${ }^{29}$ Cornel Grad, Doru E. Goran (eds), 'Documenta. Transilvania la 20 de ani după unirea: memorandumul românilor din Ardeal, Banat, Crişana, Satu Mare, Maramureş, presentat de fruntaşii P.N.Ț. regului Carol al II-lea (15 decembrie 1938)', 'Limes': Revistă trimestrială de cultură a Sălajului, vol. 2, nos 1-2, (5-6), 1999, pp. 9-29. See also, Bogdan Dumitru, 'Federalism and Regionalism in Romanian Political Thinking in the Interwar Period', Studia Universitatis Babeş-Bolyai - Studia Europaea, 57, 2012, 1, pp. 15-36 (p. 32).

30 Rebecca Haynes, Romanian Policy towards Germany, 1936-1940, Basingstoke and London, 2000, p. 62. 
interior Armand Călinescu. As the sole legal political organization in the country, the FRN fielded candidates for the puppet parliament and aped many of the external forms of fascism, such as paramilitary uniforms and the Roman salute. In an attempt to undermine the clandestine Legionary movement, all Romanians over twenty-one were expected to join the Front. The opposition to the FRN, led by Maniu, dismissed the new regime as 'ludicrous' and dubbed it the Frontul Ruşinii Naționale (Front of National Disgrace). ${ }^{31}$ Maniu declared the Front illegal and condemned those members of his party who joined it. ${ }^{32}$

While some Legionaries were prepared to enter the FRN as a condition of their release from imprisonment, others were determined to continue their opposition to the royal regime in collaboration with Maniu. ${ }^{33}$ Certain Legionaries were ready to give Maniu support in the event of violence breaking out and were even prepared to 'liquidate' the king and his mistress, Madame Lupescu, if Maniu consented. Maniu, who had long rejected Legionary violence, apparently conceded that he might be forced to accept the Legionary proposal should National Peasant Party leaders be arrested by the government. ${ }^{34}$

The early months of 1939 witnessed further attempts by the royal government at reconciliation with Germany. The enactment by Germany and Italy of the First Vienna Award in November 1938, which returned southern Slovakia to Hungary, made it crucial for Romania to retain the Reich's goodwill to prevent German support for Hungarian revisionism against Romania. ${ }^{35}$ One means of reconciliation was through an economic agreement with the Reich which would conform to the Romanian government's plans for the development of the Romanian economy and military. The negotiations were conducted, however, within an increasingly tense international context which saw Germany occupy rump-Czechoslovakia and Hungary's annexation of Ruthenia (which bordered onto Romania) on 14 and 15 March 1939 respectively. At the same time, the flight of Sima and other Legionaries into exile in Berlin in

${ }^{31}$ For the establishment of the FRN, see Radu Florian Bruja, Carol al II-lea şi partidul unic: Frontul Renaşterii Naționale, Iaşi, 2006, pp. 25-50 (pp. 41-2).

${ }^{32}$ Scurtu, Istoria PNT, pp. 338-39.

33 ANIC, Fond Ministerul de Interne, Diverse, dosar nr 7/1939, ff. 45-46, unmarked note dated 13 January 1939.

34 Hudița, Jurnal politic, vol. 2 (16 septembrie 1938-30 aprilie 1939), Bucharest, 2003, Tuesday 28 February 1939, pp. 251-52. For Carol's earlier attempts to have Maniu murdered, see Haynes, 'Reluctant Allies?', p. 131.

35 For Romania's policy towards the Reich in early 1939, see Haynes, Romanian Policy towards Germany, pp. 73-88. 
February, suggested to the royal government that the Legion had the full support of the German government. ${ }^{36}$

Such were the domestic and international tensions affecting King Carol and his government during March and April 1939 that the Manists believed that Carol was considering abdication. Maniu hoped that his continued opposition to the FRN would help force Carol's hand. ${ }^{37}$ In early March, for example, the Manists received information that Carol was apparently considering abdication and calling a Maniu-Sima government. ${ }^{38}$ At this time Maniu was busy compiling a list of some fifty arrested Legionaries, whom he believed had been executed without trial by the royal regime, and which he planned to bring to the attention of the British and French governments. ${ }^{39}$

Carol was able to ride out the tensions of spring 1939, but it was clear that a broadly-based government of national unity was required if his regime were to survive. Yet as Carol observed in his diary on 11 April 1939, the 'great flaw' of such a government would be that it would 'stir up the parties to life again and resurrect the dead, such as Maniu or Dinu Brătianu'. ${ }^{\circ}$ Nevertheless, at the end of April, Carol felt obliged to offer a number of mandates to the National Peasant Party within a future parliament with Maniu and his deputy Ion Mihalache to act as royal counsellers. Maniu refused the offer and remained determined to force the king to abdicate. ${ }^{41}$

Maniu's principled position won him the admiration of many of the Legionaries still active clandestinely in Romania. Thus, a police report of 16 June 1939 noted that one Legionary tactic was to back the most powerful opposition force against the regime, which was the National Peasant Party, 'or more exactly Maniu', while a subsequent report observed the sympathy of 'Legionary intellectuals' for Maniu due to his 'intransigent line' against the regime. ${ }^{42}$

36 The German attitude towards the Legion was, in fact, rather complex. For the attitude of German State and Party organization towards the Legion before (and during) the creation of the National Legionary State, see Rebecca Haynes, 'Germany and the Establishment of the Romanian National Legionary State, September 1940', Slavonic and East European Review, 77, 1999, 4, pp. 700-25.

37 Hudiță, Jurnal politic, vol. 2 (16 septembrie 1938 - 30 aprilie 1939), Bucharest, 2003, entries between 3 March and 30 April 1939, pp. 256-349.

${ }^{38}$ Ibid., Friday 3 March 1939, p. 256.

39 ANIC, Ministerul de Interne, Diverse, dosar nr 8/1939, f. 17, Corpul Detectivilor, Grupa I-a, nr 4, 3 March 1939.

${ }_{40}$ Nicolae Rauş (ed.), Regele Carol al II-lea al României. Însemnări zilnice, 1937-1951, 3 vols, Bucharest, 1997-2001, (hereafter, Carol al II-lea), vol. 2, 1997 [sic], 11 April 1939, p. 64.

${ }^{41}$ Hudiță, Jurnal politic, vol. 2 (16 septembrie 1938 - 30 aprilie 1939), Bucharest, 2003, Saturday 29 April 1939, pp. 347-49.

${ }^{42}$ ANIC, Ministerul de Interne, Diverse, dosar nr 9/1939, ff. 213-14, unmarked note 
It is important to note, however, that not all Legionaries supported Maniu. A police report of 1 August 1939 regarding the views of 'elements of the former Legionary leadership' reflected a less positive view of Maniu's politics. These 'elements' believed Maniu's position was no longer in keeping with 'the Romanian mentality' and therefore rejected collaboration with him..$^{43} \mathrm{~A}$ few months later, Ioan Hudiță noted in his journal that certain Legionaries did not feel that they could cooperate with Maniu beyond the immediate fight against King Carol due to his pro-Western foreign policy and belief in democracy. ${ }^{44}$

\section{The murder of Armand Călinescu, Minister of the Interior, and Maniu's reaction}

While Maniu was battling against the FRN, certain Legionary activists both in Romania and in the Berlin-based Command were preparing to avenge Codreanu's murder. On 21 September 1939, a team headed by Miti Dumitrescu, leader of the movement in Prahova county, shot Armand Călinescu in Bucharest. Călinescu was the minister of the interior who had been responsible for Codreanu's murder. ${ }^{45}$ The government's reaction was as brutal as it was swift. On 21 and 22 September, by order of Gabriel Marinescu, Călinescu's successor as minister of the interior, three Legionaries were murdered in each county and their bodies left in the streets as a warning to other Legionaries. Some four hundred Legionaries still imprisoned were also dispatched without trial, including Gheorghe Clime, Codreanu's designated successor. In one fell swoop, Marinescu's actions destroyed the remaining historic Legionary elite which had surrounded Codreanu. ${ }^{46}$

Armand Călinescu had been a National Peasant Party deputy for Argeş county but had emerged as a supporter of Carol's dictatorship which had brought him into direct conflict with Maniu and his followers. ${ }^{47}$

dated 16 June 1939; ibid., ff. 221-24, unmarked note dated 24 June 1939.

${ }^{43}$ Ioan Scurtu et al. (eds), Ideologie şi formațiuni de dreapta în România, 7 vols, Bucharest, 1996-2007, vol. 5, 1938-1940, Bucharest, 2006, doc. 159, pp. 257-58, 1 August 1939, Bucharest, Note from the Detective Corps with regard to the strategy adopted by leading Legionary circles with regard to the Carolist regime. (It is unclear who these 'elements' were, but they were possibly Legionaries who were prepared to collaborate with the royal regime.)

${ }^{44}$ Hudiță, Jurnal politic, vol . 3 (mai - decembrie 1939), Bucharest, 2004, Saturday 4 November 1939, p. 242.

45 Țiu, Mişcarea Legionară, vol. 1, pp. 139-41.

46 Ibid., pp. 144-45; Argetoianu, vol. 7, Bucharest, 2003, 25 September 1939, pp. 159-62.

47 See Haynes, 'Reluctant Allies?' p. 109 for earlier conflicts between Maniu and Călinescu. 
Consequently, although Dinu Brătianu, leader of the National Liberal Party, sent a condolence telegram to Călinescu's widow following the assassination, neither Maniu nor his deputy Ion Mihalache did so. No member of the National Peasant Party attended the funeral. ${ }^{48}$ Maniu distributed a circular to National Peasant Party leaders placing responsibility for the brutal repression of the Legionaries on the king. Maniu affirmed that the National Peasant Party could not participate in any government unless Carol abdicated following which the party would punish those responsible for the murder of the Legionaries on 21/22 September. This circular apparently made a positive impression amongst the Legionaries. Thus, according to the ministry of the interior, by early October 1939 the desire for Carol's abdication was once again widespread in the country where 'everyone speaks now only of Maniu and the Iron Guard'. ${ }^{49}$

In mid-November, politicians who supported the FRN began a propaganda campaign against Maniu in Transylvania. By the politicians' own reckoning, however, some 80 per cent of the Romanian population in the province supported Maniu, especially in those regions where he had the backing of the Legionaries..$^{5}$ In December, Wilhelm Fabricius, the German minister in Bucharest, reported that Maniu had compiled a list of some three thousand names of those killed or missing as a result of the massacre of 21/22 September. Many of these victims had apparently not even belonged to the Legion but had merely sympathized with it, or made statements against the royal regime. According to Fabricius, this had led to huge bitterness towards the government throughout Romania. ${ }^{51}$ Another member of the German Legation in Bucharest, writing in the New Year, observed that most Legionaries currently supported Maniu 'because he is the only person who protested against the shooting of Codreanu and the Legionaries, and because he was ready to come to an understanding with Codreanu..$^{2}$

${ }_{48}$ Argetoianu, vol. 7, Bucharest, 2003, 25 September 1939, pp. 159-62.

49 Reported in Hudița, Jurnal politic, vol. 3 (mai-decembrie 1939), Bucharest, 2004, Sunday 24 September to Wednesday 11 October 1939, pp. 202-14 (p. 214).

${ }^{50}$ Ibid., Saturday 12 November 1939, p. 250.

51 Politisches Archiv des Auswärtiges Amtes, Berlin, (hereafter, PA), Deutsche Gesandschaft Bukarest, IA5, Rumänien, Innenpolitisch, Bd. 9, 4.1939-1.1940: Deutsche Gesandschaft Bukarest, den 24 Dezember 1939, Tgb. nr 7819 - IA5 - An das AA Berlin, Fabricius.

${ }_{52}$ PA, Deutsche Gesandschaft Bukarest, IA5, Rumänien, Innenpolitisch, Bd. 9, 4. 1939 - 1. 1940: Aufzeichnung Bukarest den 29 Januar 1940 von Ritgen. The latter added that 'Maniu is the only person who can hold the Legionaries back from their stupidities [Dummheiten]...' 
Horia Sima, meanwhile, had managed to remain hidden during the repressions after Călinescu's murder and escaped once more to Berlin through the Banat. Before leaving Romania, Sima had instructed the Legionary Ion Nicolau to make contact with Maniu 'to discuss collaboration for the future against the common adversary. ${ }^{53}$ The authorities got wind of the situation, however, and Nicolau was arrested, but not before he had met up with Maniu on 15 December 1939 'to treat in the name of the Legionary Commander in Berlin for collaboration with the National Peasant Party' under Maniu's leadership. ${ }^{54}$ The outcome of Maniu's discussion with Nicolau is unknown, but it seems unlikely that any agreement was made between Sima and Maniu. On the contrary, the police reported on 1 February 1940 that Maniu was in possession of a copy of Codreanu's will which recommended any future leader of the movement 'to resort to the advice of the head of the National Peasant Party'. Members of the party were apparently exasperated that although he knew of the existence of this will 'Horia Sima has refused to take account of its contents..55

\section{King Carol's attempts at reconciliation with the Legion and Maniu's reactions}

From the summer of 1939 the international situation gave the country's rulers renewed cause for concern. The Romanians feared that Bessarabia had been assigned to the Soviets under the terms of the Nazi-Soviet Pact of 23 August. The subsequent invasion of Romania's Polish ally by the Germans and Soviets in September only served to increase Romania's fears of Soviet expansion. To make matters worse, during the winter of 1939/40 there was also diplomatic coordination between the Soviet Union, Hungary and Bulgaria, all of whom harboured revisionist claims on Romania. As a consequence, King Carol decided to pursue a more openly pro-German foreign policy. ${ }^{56}$ Simultaneously, he attempted to reconcile his many

${ }^{53}$ Honciuc-Beldiman (ed.), Dosar Horia Sima, doc. 17, 28 May 1940, Note of the Detective Corps regarding the interrogation of Horia Sima, pp. $103-09$ (p. 108). Ion Nicolau was an engineer at the Romanian railway Grivița-Bucharest workshop. Nicolau coordinated the so-called Corpul Răzleți (lit. corps of the scattered) composed of Legionaries with professional backgrounds who informed the exiled Command about the intentions of the Romanian authorities. Țiu, Mişcarea Legionară, vol. 1, pp. 121-36.

${ }^{54}$ ANIC, Fond Ministerul de Interne, Diverse, dosar nr 14/1939, f. 119. This is a single page of what was clearly a longer document marked 'Anexa $\mathrm{nr} 6$ '.

${ }_{55}$ Scurtu et al. (eds), Ideologie şi formațiuni de dreapta în România, vol. 5, 1938-1940, doc. 207, 1 February 1940, Bucharest, Informative Bulletin of the General Directorate of Police containing information from National Peasant circles with regard to the political will of Corneliu Zelea Codreanu, p. 308.

56 For what follows on Romania's fears of the Soviet Union and consequent 
internal political opponents in defence of Romania's territorial integrity. Even members of the government believed the FRN existed only on paper and had failed to penetrate public opinion in the towns and villages, where one minister feared 'the Manists and Legionaries are masters of the situation. ${ }^{57}$ Thus, late in 1939 another possible coalition between the FRN and the National Peasant Party was suggested, with Ion Mihalache to serve as vice-president. This proposal was once again rejected by Maniu. ${ }^{58}$

The king's policy of repression of the Legion was also now transformed into one of reconciliation. Believing that the Legion had the full backing of the Germans, Carol felt he could not pursue rapprochement with the Reich without a government inclusive of the Legionaries. Carol thus removed Gabriel Marinescu, who had overseen the massacres of 21/22 September 1939, from his position as minister of the interior and installed in his place the former National Peasantist Mihail Ghelmegeanu. The latter was now charged with forging links with the Legionaries. The popular Legionary leader of Arad county, Dr Vasile Noveanu, was the first to give up opposition to the king in the spring of 1940. Noveanu now became the core of a Legionary faction which was in favour of reconciliation with the regime. $^{59}$

The opposition gathered around Maniu and Dinu Brătianu observed this cooperation between the king and elements of the Legionary movement with misgiving, fearing that it would strengthen Carol's position. Maniu therefore decided on a plan of sabotage. Accordingly, close colleagues were to approach Jewish financial leaders and Franco-British diplomatic circles to inform them that the planned rapprochement between the king and the Legionaries had been demanded by the Reich and would lead to antisemitic campaigns. Maniu was fully aware that for his plan to succeed, it was imperative to prevent Carol reaching agreement with the Berlinbased Command under Sima. His secretary, Aurel Leucuția, was therefore sent to Berlin to transmit Maniu's message that the majority of Legionaries in Romania were, so he claimed, unsympathetic to the Noveanu group's inclusion in the FRN and that the king was insincere in his approach to the

rapprochement with the Reich from the autumn of 1939 to June 1940, see Haynes, Romanian Policy towards Germany, pp. 119-44.

57 Ioan Hudița, Jurnal politic, 3 vols (with an introduction by Dan Berindei), Iaşi, 19982002, vol. 1 (1 ianuarie - 5 septembrie 1940), 1998, Wednesday 21 February 1940, pp. 72-73. The minister who made this remark was Constantin Giurescu.

${ }^{58}$ For the constant reorganization of the FRN in late 1939 and early 1940, see Bruja, Carol al II-lea şi partidul unic, pp. 186-200.

${ }^{59}$ Horia Sima, Sfârşitul unei domnii sângeroase, Timişoara, 1995, pp. 31-32. 
movement. Maniu's message also stressed that he was dedicated to fighting against the royal regime to the bitter end and he requested that the Berlin Legionaries support his action. To do so, however, they were to accord Maniu their 'full confidence and liberty of action in questions of external and internal politics' and transmit to the Legionaries still in Romania an order to enrol in National Peasant Party formations. Maniu apparently placed 'much hope in the support of the Legionary leaders who remain outside the present [FRN] regime and in general in all those who do not join with the action of the Noveanu group'.

King Carol was similarly determined to court the Command which claimed ultimate authority over the Legionary movement as a whole. A delegation from the Vasile Noveanu group was duly sent to Berlin on 28 March 1940. Sima refused, however, any collaboration with the king without a change of foreign-policy in favour of the Axis. ${ }^{61}$ Despite this set-back, the process of reconciliation between the king and the Noveanu group within Romania continued and in late April 1940, Carol granted the Legionary movement an amnesty. ${ }^{62}$ Nevertheless, when a further delegation from the king arrived in Berlin at the beginning of May, Sima repeated his demand for a pro-Axis foreign policy. He issued a manifesto claiming that only Germany could save Romania from the territorial revisionism of her neighbours. ${ }^{63}$

\section{Horia Sima's return to Romania and reconciliation with King Carol}

Notwithstanding these developments, the momentum was moving against the Noveanu group and in favour of Sima. Crucially, it was still Sima, rather than Noveanu, who controlled the local organizations in Romania which he had organized in 1938 and which were capable of terrorist actions. ${ }^{64}$ Sima, together with Nicolae Petraşcu, left Berlin for Romania on 5 May to carry out a coup against the king. Sima was, however, apprehended and arrested in the Banat on 19 May 1940. He was taken for interrogation by the minister of the interior, Ghelmegeanu, and subsequently by Nicki Ştefănescu, the

${ }^{60}$ Arimia et al. (eds), Istoria Partidului Național Țărănesc: documente 1926-1947, doc. 42, 18 March 1940, Note of the security police regarding activities undertaken by Iuliu Maniu against the Carolist government, pp. 193-97 (pp. 195, 196).

61 Sima, Sfârşitul, pp. 44-53; Ţiu, Mişcarea Legionară, vol. 1, pp. 167-68.

${ }^{62}$ Carol al II-lea, vol. 3 (15 decembrie 1939 - 7 septembrie 1940), Bucharest, 1998 [sic], 24 April 1940, pp. 145-46. Under seven decrees issues during April and May 1940, Legionaries accused of illegal activities were freed. See T,iu, Mişcarea Legionară, vol. 1, p. 167.

63 Sima, Sfârşitul, p. 44.

64 There were some twenty-two such organizations. See Țiu, Mişcarea Legionară, vol. 1, p. 172 . 
director general of the security police, between 21 and 25 May. ${ }^{65}$ On 26 May Sima met General Mihail Moruzov, the director of the military secret service, who advised Sima of the king's desire for a change in Romania's foreign policy and Legionary participation in the royal regime. ${ }^{66}$

International events now took a further turn in Sima's favour. The capitulation to Germany on 28 May of the Belgian government, whose policy of neutrality towards the Great Powers had provided the model for Romania's own official neutrality policy, brought about the Romanian government's decision to pursue 'active collaboration with Germany in all domains. ${ }^{67}$ Between 28 May and 7 June Sima met Legionary delegations throughout Romania with a view to the full integration of the movement into the FRN. On 13 June, Sima was liberated by the royal authorities and gave his consent for full-scale collaboration between the Legion and the king. ${ }^{68}$ Crucial at this stage for Sima's success was the widely-held belief that the Germans fully supported the Berlin-based Legionaries. This perception of Sima as having German backing naturally weakened the position of the Noveanu group vis-à-vis the king. ${ }^{69}$

It is instructive to note Sima's negative attitude towards Codreanu and Maniu during his interrogation by the Romanian authorities as he moved from a position of animosity towards Carol to one of compromise which offered him the possibility of political power. In late 1938, at the time of his terrorist attacks in Transylvania, Sima had produced a propaganda sheet attacking the king as a tyrant and extolling the virtues of Maniu, Codreanu and General Ion Antonescu, who was also an adversary of the king. Having excoriated Carol, Sima concluded that 'the holy ideas of Codreanu will triumph. [...] Iuliu Maniu, General Antonescu and Corneliu Codreanu will be raised up like giants in the political history of Romania, while history will speak of Carol II as a Nero'? ${ }^{70}$

In contrast, on 24 May, the security police noted that in 'talking about Corneliu Codreanu, Horia Sima told us that 'if, in truth, he [Codreanu]

${ }^{65}$ For Sima's account of his discussions and interrogations, see Sima, Sfârşitul, pp. 89-103.

${ }^{66}$ Ibid., pp. $103-05$.

${ }^{67}$ Haynes, Romanian Policy towards Germany, p. 132.

${ }^{68}$ Sima, Sfârşitul, pp. 107-16.

69 Țiu, Mişcarea Legionară, vol. 1, p. 172.

70 Honciuc-Beldiman (ed.), Dosar Horia Sima, doc. 1, 19 May 1940, Note of the Detective Corps regarding the evolution of the Legionary movement in the period 1938-1940 and the evaluation of the possibilities of subordinating it to Carolist politics, pp. 5-52 (annex no. 8, 'Children, Young People and the Elderly!' pp. 45-48 [p. 47]). For Antonescu's clashes with Carol in the 1930s, especially over army reform, see Larry Watts, Romanian Cassandra: Ion Antonescu and the Struggle for Reform, 1916-1941, Boulder, CO, 1993, pp. 75-105. 
had the opportunity to come to an agreement with His Majesty the King and he did not do so, he committed the greatest political mistake, without which the Legionary movement would not have fallen to its current low' ${ }^{71}$ The following day, Sima played down his exchange of information with Maniu, conducted through the lawyer Horia Cosmovici. Sima informed his interrogators that he had maintained the line of communication only because Maniu also wanted a change of regime, and thus 'contact was imperative'. ${ }^{72}$ On 3 June, following further discussions with the police and Mihail Moruzov, director of the military secret service, Sima concluded that 'His Majesty the King has been regarded in a false light, to which numerous factors have contributed, starting with Corneliu Codreanu and ending with Iuliu Maniu' ${ }^{73}$

In keeping with his apparent new-found faith in the king, Sima had his first audience with Carol on 18 June. Sima suggested to the king the creation of an authoritarian political organism to replace the FRN and promote national solidarity. Sima opined that only alliance with the Axis could now save Romania and concluded that the king could have faith in the the Legionaries. ${ }^{74}$ The following day, two legionaires, led by Niki Ştefănescu, head of the security police, travelled to Berlin to secure the final re-conciliation of the remaining Berlin-based Legionaries with the royal regime. ${ }^{75}$ On 22 June, Romania's French ally submitted to the invading Germans and Carol issued a decree reflecting Sima's proposals for a new Party of the Nation (Partidul Națiunii), into which the Legion was to be integrated. This authoritarian party, under the supreme leadership of the king, was consciously imitative of the NSDAP. ${ }^{76}$ The opposition around Maniu naturally refused to join the new organization. Ion Mihalache, who had become a royal counsellor on 17 April, resigned on 26 June. $^{77}$

71 Honciuc-Beldiman (ed.), Dosar Horia Sima, doc. 11, 24 May 1940, Note of the Detective Corps regarding the interrogation of Horia Sima, pp. 66-71 (pp. 69-70).

72 Ibid., doc. 12, 25 May 1940, Note of the Detective Corps regarding the interrogation of Horia Sima, pp. 71-81 (pp. 74-75).

73 Ibid., doc. 20, 3 June 1940, Note of the Detective Corps regarding measures recommended by Horia Sima for collaboration between the Legionary movement and the Carolist regime, pp. 113-17 (p. 114).

74 'He seems sincere', Carol noted in his diary. Carol al II-lea, vol. 3, 18 June 1940, pp. 206-07.

75 PA, Politische Abteilung IV: Po5, Vol. 5, 2.39-6.40, German Legation in Bucharest to the Foreign Ministry, Tel. nr 941, 19 June 1940, signed Fabricius.

${ }^{76}$ Armin Heinen, Die Legion 'Erzengel Michael' in Rumänien. Soziale Bewegung und politische Organisation, Munich, 1986, p. 421. For the full history of the Party of the Nation, see Bruja, Carol al II-lea şi partidul unic, pp. 205-48.

77 Scurtu, Istoria PNT, p. 342. 
But these political changes did not save Romania from her fate. On 26 June, with German troops concentrated in the west, the Soviet Union issued Romania with an ultimatum to cede Bessarabia and northern Bukovina. On German advice the Crown Council accepted the Soviet demand early on 28 June. Later that day, Carol established a new 'Germanfriendly' cabinet which included Horia Sima as sub-secretary of state at the Ministry of Education. ${ }^{78}$ In view of fears of further territorial truncation by Romania's revisionist neighbours, Hungary and Bulgaria, Sima was reluctant to accept his post and did so only under pressure from the minister of the palace, Ernest Urdăreanu. The following day, Sima attempted to convince Carol that Romania could only be saved by the establishment of a government under his (Sima's) presidency. ${ }^{79}$

Carol rejected Sima's suggestion, but the king's position was desperate. He presided over a highly unpopular regime and his truncated country was diplomatically isolated. Romania's Polish and French allies were defeated and the future of Great Britain was uncertain. Consequently, on 2 July Carol made the first of a number of requests for a German military mission to be sent to Romania to reorganize the Romanian army and air force. On 4 July, Carol created a new government with Ion Gigurtu as minister president and Mihail Manoilescu as foreign minister. Both were friendly to the Axis and the Legion. Sima was elevated to the post of minister for (religious) cults and arts, while Vasile Noveanu and another member of his group, Augustin Bidianu, became minister for public wealth and under-secretary of state at the ministry of finance respectively. ${ }^{80} \mathrm{On}$ 7 July, however, Horia Sima, resigned, informing Carol that he could not participate in a government which might be forced to preside over further territorial amputations of Romania. ${ }^{81}$ Sima now busied himself with his radical supporters in Bucharest and continued to apply pressure on the king for a change of government. On 7 August he headed a delegation of Legionaries to the king and argued that the defence of Romania could only be secured by a new regime, purged entirely of the older generation of politicians. 'Horia Sima', wrote the king in his diary, 'concluded that the party should be Legionary, headed by a king of the Legionaries. I replied that I am the king of the Romanians' ${ }^{82}$

${ }^{78}$ Haynes, Romanian Policy towards Germany, pp. 135-36.

79 Carol al II-lea, vol. 3, 28 June 1940, pp. 224-25.

${ }^{80}$ Haynes, Romanian Policy towards Germany, pp. 146-47.

${ }^{81}$ Carol al-II lea, vol. 3, 8 July 1940, p. 240.

${ }^{82}$ Ibid., 7 August 1940, pp. 267-70 (p. 270). 
In the midst of this unprecedented domestic and international turmoil, Sima and his supporters continued to maintain an equivocal position towards Maniu. On 2 August, the police reported that Sima, perceptively as events were to show, believed that Maniu would not succeed in convincing Carol to return to a constitutional regime. Maniu's action was thus to the advantage of the Legion as the lack of reconciliation between Maniu and the king would of necessity eventually lead to a Legionary government. ${ }^{83}$ This opinion did not, however, prevent Sima from attempting to make contact with Maniu in early August in order to discuss Hungary's revisionist pressure on Transylvania. ${ }^{84}$ Indeed, it seems that in the summer of 1940, Sima had a number of meetings with Maniu, although the content and outcome of these meetings is unknown. ${ }^{85}$

\section{Hungarian and Bulgarian revisionism: Legionary and Manist reactions}

The creation of a pro-German cabinet did not, however, prevent the German government pressurizing the Romanians to negotiate directly with their revisionist neighbours, Hungary and Bulgaria. ${ }^{86}$ Carol once again attempted to widen participation to the royal government in order to make a firm stand against Romania's dismemberment. On 26 August, Carol offered five ministerial portfolios to the Manists, but Maniu, still hopeful of forcing the king's abdication, advised his followers to 'neither reject nor accept the offer, ${ }^{87}$ On 28 August Carol contrived to draw Sima into the government once more but this failed owing to Sima's renewed demand for a pure, Legionary regime. ${ }^{88}$ It would prove to be Sima's last attempt to establish a Legionary government in cooperation with the king.

Maniu, meanwhile, was strengthening his links with the Transylvanian Legionaries in order to resist Hungarian revisionist demands. On 13 August he informed his followers that he believed the Legion's incorporation into his resistance front would show the Germans that public opinion

83 ANIC, Fond Direcția Generală a Poliției, dosar nr 251/1940, f. 355, 2 August 1940, Corpul Detectivilor, Grupa I-a, nr 41, Horia Sima and Iuliu Maniu's activity.

${ }^{84}$ Ibid., f. 362, 3 August 1940, Corpul Detectivilor, Grupa I-a, nr 4.

85 On 15 November 1940 Maniu confirmed that before Carol's abdication on 6 September, Sima had 'frequent and important meetings' with him. ANIC, Fond Preşedinția Consiluilui de Miniştri: Cabinet Militar, 1940-1944, dosar nr 199/1940, 35 ff of an unmarked document covering the events of 11 September to 22 November 1940 (f. 14).

${ }^{86}$ For the negotiations with Bulgaria and Hungary and for full details of the Second Vienna Award of August 1940, see Haynes, Romanian Policy towards Germany, pp. 148-59.

87 ANIC, Fond Preşedinția Consilului de Miniştri: Cabinet Militar, 1940-1944, dosar nr 117/1940, f. 292, D.S., 26 August 1940.

${ }^{88}$ Carol al-II lea, vol. 3, 28 August 1940, pp. 288-89. 
in Romania was universally opposed to the loss of territory to Hungary. Maniu also hoped that the Legion's affiliation with his resistance would make clear to the royal government the extent of its isolation from the majority of Romanians. Links between the Transylvanian Legionaries and the Manists were being maintained through Virgil Solomon and Zaharia Boilă, Maniu's nephew. Solomon had been instrumental in coordinating links with Legionaries in Transylvania since at least 1938, and Boilă had played a critical role in bringing Maniu and Codreanu together in the 1930 . Boilăs negotiations in the summer of 1940 now led to many Transylvanian Legionaries agreeing to common action with Maniu. Indeed, these Legionaries were even disposed to pressurize their leaders in Bucharest to agree to the whole movement joining Maniu's resistance front. ${ }^{89}$ On 21 August, the police reported that Boilă was putting together 'committees of action' throughout Transylvania. To that end, Boilă had made contact with some one hundred leaders of various political colourings, including Legionaries. $^{90}$

The Transylvanian issue was, however, now taken out of the hands of Romania and Hungary, whose diplomats had proved unable to reach a settlement. On 29 August the foreign ministers of the two countries were summoned to Vienna by the German and Italian governments to witness an unconditional arbitration by the Axis of the Transylvanian dispute. According to the Second Vienna Award, Romania lost northern Transylvania and southern Dobruja to Hungary and Bulgaria respectively. In exchange, the Romanian government received a guarantee of what remained of its territory, and the dispatch of a German military mission to Romania. An expanded Crown Council, fearing a combined attack by the Soviet Union and Hungary, reluctantly decided to accept the arbitration on the night of 29/30 August. ${ }^{91}$ In his diary entry for 30 August, Carol considered abdication since he believed that hatred against him for accepting the Award was inevitable. He anticipated that the opposition towards him would be coordinated by 'Maniu and the Iron Guard'. ${ }^{2}$

${ }^{89}$ ANIC, Fond Direcția Generală a Poliției, dosar nr 251/1940, ff. 345-6, Directorate of the security police, Group I-a, nr 4, 14 August 1940. For Solomon and Boilă’s Legionary links in the 1930s, see Haynes, 'Reluctant Allies?', pp. 114, 130.

90 ANIC, Fond Direcția Generală a Poliției, dosar nr 34/1940, ff. 107-48 (119), Police Prefecture of the Capital, Security Police, Information Section, Informative Report, 21 August 1940.

${ }_{91}$ Haynes, Romanian Policy towards Germany, pp. 151-53.

92 Carol al II-lea, vol. 3, 30 August 1940, pp. 291-95 (p. 293). 
Horia Sima, meanwhile, had wisely stayed away from the crucial meeting of the Crown Council and was thus uncompromised by the regime's acceptance of the loss of territory. On 31 August he was finally officially recognized as head of the Legionary movement by a group of some forty-eight senior Legionary figures led by founder-member Radu Mironovici. ${ }^{93}$ On 1 September Sima issued the first of his demands for Carol's abdication. On the same day Maniu sent telegrams to Hitler and Mussolini protesting against the loss of northern Transylvania. ${ }^{94}$

\section{Maniu and Transylvanian autonomy}

At this point, it is appropriate to return to Maniu's ostensible backing for Transylvanian autonomy. Maniu had supported Transylvania's union with Romania after the Great War. It seems, nonetheless, that he had favoured autonomy for Transylvania for the first ten years of the union with Romania, and regarded the decision taken at Alba Iulia on 1 December 1918 for unconditional union as having been taken without the consent of the people. ${ }^{95}$ Moreover, it has been noted above that some of the Manist and Legionary anti-government actions in late 1938 and 1939 included demands for Transylvanian autonomy, although it is unclear how serious these demands were. Nevertheless, Maniu's activities took place within the context of increasing resentment towards the royal government regarding its treatment of Transylvania and the Banat, which his memorandum of 15 December 1938 was designed to address.

Under the pressure of Hungarian revisionist demands in the summer of 1940, however, government sources reported that demands for autonomy were gaining ground amongst Transylvanians, and not only amongst the

${ }^{93}$ Honciuc-Beldiman (ed.), Dosar Horia Sima, doc. nr 32, 31 August 1940, Appeal of the Legionary leaders for the recognition of Horia Sima as head of the Legionary movement, pp. $170-71$.

94 Scurtu, Istoria PNT, p. 352.

95 Carol al II-lea, vol. 1 (11 martie 1937 - 4 septembrie 1938), Bucharest, 2001 [sic], 12 July 1938, pp. 198-200: Carol noted this in his diary following a conversation with Patriarch Miron Cristea, himself a Transylvanian who had been present at the Alba Iulia discussions. For Maniu's role at Alba Iulia and as president of the Consiliului Dirigent which oversaw Transylvania's incorporation into Greater Romania, see Stan, Iuliu Maniu, pp. 58-114. Many Transylvanian Romanians quickly became disillusioned with the union. The Transylvanian National Peasant Party deputy, and subsequent ambassador to London, Viorel Tilea, for example, spoke in favour of Transylvanian autonomy as early as 1928 owing to disenchantment with the National Liberal Party's electoral corruption. Conversation with Viorel Tilea's daughter, Ileana Troiano, on 30 December 2007. On Transylvanian regionalism in the 1920s, see also, Irina Livezeanu, Cultural Politics in Greater Romania: Regionalism, Nation Building \& Ethnic Struggle, 1918-1930, Ithaca, NY and London, 1995, pp. 129-87. 
province's Romanian population. ${ }^{96}$ According to a police report of 22 August Maniu was sounding out official Hungarian circles in Transylvania regarding their views on the Romanian-Hungarian territorial dispute. Maniu had spoken with Count Nicholas Bánffy, president of the Magyar community in Transylvania. The Hungarian magnates favoured a union of Transylvania in its entirely with Hungary, but Maniu discovered that the Hungarian community's non-nobles (in particular, representatives of Hungarian intellectuals, youth and peasantry) had no desire for any cession of territory to Hungary. Maniu was therefore able to collaborate with these sectors of the Magyar minority. Their representatives agreed to appoint Maniu as president, with two vice-presidents to be selected from the Transylvanian Magyar and German communities in the event of autonomy being declared. Maniu's close collaborators reported, however, that Maniu personally regarded autonomy as an extreme solution to the resolution of the Transylvanian problem. ${ }^{97}$ Nevertheless, according to Dr Gerhard Stelzer, a member of the German Legation in Bucharest, following the disclosure of the Vienna Award on 31 August Maniu was even prepared to proclaim the full independence of Transylvania in the event of the Romanian government ceding territory. ${ }^{98}$ Maniu and other National Peasant Party leaders agreed to organize a resistance movement throughout the whole of Transylvania through the creation of county committees and a central committee which would, if necessary, take an 'intransigent attitude even towards the Regat'. In the event of violence being necessary to protect Romanian-inhabited areas from Hungarian encroachment, Maniu and the National Peasant Party leaders agreed to establish a voluntary corps called the National Guard of Transylvania. General Negrei and three other military officers were to lead the National Guard. All four of these military men had resigned their commissions in the Romanian army as a consequence of King Carol's acceptance of the Vienna Award.99

${ }^{96}$ ANIC, Fond Președinția Consilului de Miniştri: Cabinet Militar, 1940-1944, dosar nr 117/1940, ff. 8-12 (9), Note, 22 August 1940.

97 ANIC, Fond Direcția Generală a Poliției, dosar nr 137/1940, ff. 132-4, D.S., 22 August 1940.

${ }_{98}$ Cristian Scarlat (ed.), Diplomați germani la Bucureşti 1937-1944. Din memoriile dr Rolf Pusch, ataşat de legație şi dr Gerhard Stelzer, consilier de legație, Bucharest, 2001, pp. 124-25. Dr Stelzer was first counsellor at the German Legation from May 1938 to August 1944.

99 ANIC, Fond Direcția Generală a Poliției, dosar nr 137/1940, ff. 57-8, no date. General Negrei was arrested by the Legionary police in October 1940 for circulating revisionist leaflets demanding the return of northern Transylvania: Pelin, Iluziile lui Iuliu Maniu, p. 34. 
Maniu's response to the Vienna Award also involved coordinating his activities with the Legionaries. The latter were, however, divided in their response to the Award. Some Legionaries, including two of the movement's founders, Radu Mironovici and Illie Gârneața, favoured fighting Hungary and wished to abandon the movement's official pro-Axis position in favour of rapprochement with the Soviet Union. These two Legionaries contacted Maniu and Ion Mihalache on 31 August, seeking their support for military collaboration with the Soviet Union. Sima, however, as leader of the movement, adhered to Codreanu's original pro-Axis position, arguing that despite the Vienna Award the Axis would ultimately support Romania in regaining her lost territories. ${ }^{100}$ Nevertheless, it seems Maniu was prepared to endorse Mironovici and Gârneața's proposition. According to German security sources reporting on 5 September, as protests demanding Carol's abdication were reaching their climax, Maniu apparently intended to proclaim Transylvanian autonomy and place the province under Russian protection. Simultaneously, General Cornel Dragalina, who had been dismissed from his post by King Carol for refusing to carry out the stipulations of the Vienna Award, was prepared to call for the autonomy of Transylvania and then place the area under German protection with the assistance of the Soviets. The German source confirmed that the Transylvanian Legionaries were collaborating with Maniu and that 'without doubt a call for Transylvanian autonomy would find a unanimous echo in all Transylvanian circles'. The source noted that the Legionary leadership was, however, distancing itself from the autonomist demands. ${ }^{101}$ On 3 September Sima declared to the movement that Romania was obliged to accept the stipulations of the Award and that the loss of territory was the direct result of the royal regime's anti-Axis foreign policy. Sima ordered the Legionaries to cease their contacts with the Manists and prepare for government. ${ }^{102}$

100 ANIC, Fond Direcția Generală a Poliției, dosar nr 35/1940, ff. 181-225 (pp. 185-86), Police Prefectura of the Capital, Police Service, Information Section, Informative Report, 31 August 1940.

101 PA, Inland II geheim: Berichte und Meldungen zur Lage in und über Rumänien: Band 1, Bd. 422, 1937-1940: Der Chef der Sicherheitspolizei und des SD VID 3-Pra./Wi. Berlin den 5 September 1940. An den Reichsminister des Auswärtigen-Auswärtiges Amt z.HD. von Herrn Gesandten Luther. Bericht über die gegenwärtige Lage in Rumänien: SS Sturmbahnführer.

102 ANIC, Fond Preşedinția Consilului de Miniştri: Cabinet Militar, 1940-1944, dosar nr 117/1940, f. 233, 3 September 1940; ibid., f. 273, unmarked note, no date. 


\section{The establishment of the National Legionary State and Maniu's reaction} On 1 September Sima made his first demand for Carol's abdication. ${ }^{103}$ The following day, Carol noted in his diary that animosity towards him was growing as a result of his acceptance of the Vienna Award, especially in the army. Maniu and other important figures were now demanding that he relinquish power. ${ }^{104}$ Between 3 and 6 September a series of popular demonstrations against the Vienna Award erupted across Romania. These were co-ordinated by the Legionaries and their supporters amongst the junior officers in the army. ${ }^{105}$ Carol's subsequent abdication and the creation of the National Legionary State have frequently been portrayed as having been orchestrated by Germany. This was, however, far from being the case. ${ }^{106}$ A statement written by Maniu and Dinu Brătianu, and originally published in Timpul on the day that the National Legionary State was proclaimed (14 September 1940) highlighted the importance of domestic factors in Carol's fall from power. His abdication had been 'loudly proclaimed by public opinion' and was the result of his 'general conception of personal rule which lacked ideals, principles or stability and which [...] created an abyss between himself and his people. ${ }^{107}$ The unpopular royal regime, which had barely sustained the loss of Bessarabia and northern Bukovina, could certainly not survive the loss of much of Transylvania, which was seen as integral to Romanian nationhood and identity.

Nevertheless, the Germans had long favoured a royal regime headed by Carol, with 'tame' Legionaries and other pro-German elements brought into his government. The German attitude changed only as a result of the popular demonstrations against Carol in early September over which the Reich had no control. The Germans now supported General Antonescu as leader of the Romanian state, despite his pro-Western past, as he was prepared to implement the Vienna Award and welcome the German military mission to Romania, as originally requested by King Carol. ${ }^{108}$

${ }^{103}$ Sima, Sfârşitul, pp. 207-08.

${ }^{104}$ Carol al II-lea, vol. 3, 2 September 1940, pp. 295-97.

105 Maniu's role in these demonstrations, many of which had a pronounced antiGerman flavour, is unclear. He had, however, been in contact with members of the British Special Operations Executive since the summer of 1940 and had agreed with them to an anti-German uprising in Transylvania following the Second Vienna Award. Ivor Porter, Operation Autonomous: With S.O.E. in Wartime Romania, London, 1989, pp. 53-54.

${ }_{106}$ For the events of 3 to 6 September, German reactions and the creation of the National Legionary State, see Haynes, 'Germany and the Establishment of the Romanian National Legionary State', pp. 700-25.

107 Quoted in ibid, p. 724.

${ }^{108}$ For Antonescu's pragmatic attitude towards Germany, see ibid., esp. p. 716; Dennis Deletant, Hitler's Forgotten Ally: Ion Antonescu and His Regime, Romania 1940-1944, 
On 4 September angry crowds surrounded the royal palace and on the following day Carol invested Antonescu with dictatorial powers. On 6 September, with all parties (most significantly Maniu, Dinu Brătianu and Sima) demanding Carol's abdication and large crowds continuing to protest outside the palace, Antonescu received the king's abdication. Carol, together with his mistress, Madame Lupescu, fled Romania into exile. With the king gone and his young son, Michael, proclaimed king, the issue now was what kind of regime to install.

It has been said that 'through the abdication of Carol II, Iuliu Maniu obtained one of the most important victories of his political career. ${ }^{109}$ But the overthrow of the Carolist regime was also Horia Sima's victory. In the event it was Sima, rather than Maniu, who was able to capitalize on Carol's abdication, albeit that the new regime was not the purely Legionary government which Sima had hoped for during the summer of 1940. Rather, the new government was one in which the Legion was forced to share power with General Antonescu as a result of pressure exerted on Sima by the German minister in Bucharest, Wilhelm Fabricius. ${ }^{110}$

It appears that Maniu had expectations of leading the new government after Carol's abdication. In a secret meeting held between Antonescu and Maniu back in October 1939 to discuss joint policy towards the royal dictatorship, the two men had agreed to a national government following Carol's overthrow. Antonescu was to act as minister of national defence and vice-president of a government presided over by Maniu. This proposed government was to include two Legionaries as well as a representative of the socialist and communist parties. Maniu and Antonescu's agreement had envisaged that Romania would remain a monarchy and allied to the West. ${ }^{111}$ Following Antonescu's incarceration in Bistrița monastery by Carol in July 1940, it was Maniu who organized Antonescu's release at the end of August. Between 1 and 4 September Maniu and Antonescu, encouraged by the British Special Operations Executive, had several

\section{Basingstoke, 2006, pp. 51, 54.}

109 Scurtu, Istoria PNT, p. 355. Scurtu argues that Maniu should have appealed to the masses for the restoration of democracy after Carol's abdication, but everything indicates that the masses were supporting the Legion at that time and would not have been stirred by a rallying call for a democratic regime. Speaking at his trial, Antonescu confirmed that had he held elections in 1940, the Legionaries would have won by a large majority. MarcelDumitru Ciucă, (ed.), Procesul Mareşalului Antonescu. Documente, 3 vols, Bucharest 1995-1998, vol. 3, 1998, p. 364.

110 Hudița, Jurnal politic, vol. 1 (1 January 1940 - 5 September 1940), Iaşi, 1998, Tuesday 3 September 1940, p. 312.

111 Hudița, Jurnal politic, vol. 3 (May - December 1939), Bucharest, 2004, Monday 16 October 1939, pp. 220-21. 
meetings to discuss the creation of a pro-British government which would refuse to implement the Vienna Award. ${ }^{112}$ It appears that on the night of 3-4 September, an agreement was reached between Antonescu, Maniu and Dinu Brătianu, which was subsequently broken by Antonescu. Thus, on 6 September when Carol abdicated and Antonescu assumed power as leader of state, Maniu stated that 'Antonescu has not respected the commitment made towards myself and [Dinu] Brătianu to avoid any solution which did not have as its basis the abdication of Carol and the creation of a national government under my presidency. ${ }^{113}$

Nevertheless, it appears that Antonescu initially intended to form a national government with the Legionaries which would also include members of the National Liberal and National Peasant parties. The fact that a single-party National Legionary State was created in which the Legionaries held the lion's share of crucial positions was due in part to in-fighting between National Liberal factions and Maniu's (and Dinu Brătianu's) unwillingness to share power with the Sima-led Legionaries. ${ }^{114}$ As Maniu later explained, the National Peasant Party could not collaborate with Antonescu as he had come to an agreement with Sima who was both antisemitic and in favour of a dictatorship, while the National Peasants rejected antisemitism and sought a return to a constitutional regime. ${ }^{115}$

A police report dated 1o September 1940 reveals that Maniu's attitude to the new regime was also coloured by his belief in the ultimate victory of Britain and her allies in the war. In preparation for this Western victory, Maniu believed that the Romanian state required a democratic regime with the traditional political parties re-established. While he recognized that it was currently necessary for Romania to be allied to the Axis, Maniu anticipated that the international situation would soon change in favour of Britain and the Western democracies. It was essential for a part of the Romanian political establishment to act as a reserve for the time when this

112 Traian D. Lazăr, Iuliu Maniu şi serviciile secrete, Bucharest, 2006, pp. 31-46.

${ }^{113}$ Hudița, Jurnal politic, vol. 1 (1 januarie 1940 - 5 septembrie 1940), Iaşi, 1998, Friday 6 September 1940, pp. 321-24 (p. 321). See also, ibid., vol. 2 (7 septembrie $1940-8$ februarie 1941), Iaşi, 2000, Saturday 1 February 1941, pp. 250-52.

${ }^{114}$ Haynes, 'Germany and the Establishment of the Romanian National Legionary State', pp. 721-22. It is also true that even if Maniu and Dinu Brătianu had been prepared to enter the government, the presence therein of two pronounced pro-Westerners who rejected the legality of the Vienna Award would not have been tolerated by the Germans: Ottmar Traşcă, 'Totalitarismul în România: aspect ale relațiilor dintre Generalul Ion Antonescu şi Mişcarea Legionară în perioada guvernării national-legionare (septembrie 1940 - februarie 1941)', Anuarul institutului de istorie din Cluj, 36, 1997, pp. 197-221 (pp. 199-200).

${ }^{115}$ Ciucă, Procesul Mareşalului Antonescu: Documente, vol. 2, Bucharest, 1997, p. 53. 
occurred. Thus, although Maniu accepted General Antonescu's actions up to this point, he opposed the political system Antonescu was inaugurating. Maniu advised members of the National Peasant Party to trim their sails and neither concretely support Antonescu nor oppose him. ${ }^{116}$

The National Legionary state was proclaimed on 14 September and the government was finalized on the night of 14/15 September with Antonescu as minister president and head of state and Sima as vice-president and Legionary commander. The strength of the Legion was reflected in their hold on the crucial ministry of the interior, as well as a number of other important ministries such as foreign affairs, and press and propaganda. In addition, Legionaries heading up the police services and the security police (Siguranța). Two members of the National Liberal party held the ministries of national economy and finance. All institutions created by Carol II were dissolved. ${ }^{117}$ The National Peasant Party was only represented in the new government in the form of some technical experts. ${ }^{118}$

\section{Maniu and the Legionaries during the National Legionary State}

Despite Maniu's refusal to collaborate with a government dominated by Legionaries, he did not believe it possible for anyone to govern Romania within the current international context without reference to the Legion. The huge Legionary demonstration of 6 October, in which even the staid General appeared wearing the Legionary green shirt, clearly made a great impression on Maniu. He subsequently confirmed that he would make no difficulties for the regime provided the interests of the country were not placed in jeopardy. ${ }^{119}$ On 15 October, German security sources reported

116 ANIC, Fond Direcția Generală a Poliției, dosar nr 137/1940, ff. 148-51, 10 September 1940. Attitude of the National Peasants towards the new regime. (Antonescu also recognized the need for channels of diplomatic communication with the West to be open in case the Axis did not win the war. Hence, the political parties were dissolved de jure during the National Legionary State and the subsequent Antonescu military regime, but the National Peasant and National Liberal parties were recognized de facto. Their links with diplomats were tolerated and the Gestapo were forbidden from harassing party members. Scurtu, Istoria PNT, p. 365. For Maniu's support for Antonescu during the Second World War, see Deletant, Hitler's Forgotten Ally, esp., pp. 55 and 74-75.

${ }^{117}$ For a full list of post-holders, see Haynes, 'Germany and the Romanian National Legionary State', p. 722. In addition, of the countries forty-six new prefects announced on 21 September, the majority were Legionaries: Ottmar Traşcă, 'Totalitarismul în România: aspect ale relațiilor dintre Generalul Ion Antonescu şi Mişcarea Legionară în perioada guvernării național-legionare (septembrie 1940 - februarie 1941)', p. 200.

118 Lazăr, Iuliu Maniu şi serviciile secrete, p. 55.

119 Ion Calafeteanu (ed.), Iuliu Maniu - Ion Antonescu. Opinii şi confruntări politice 1940-1944, Cluj, 1994, doc. 20, Report on the activities of the National Peasant groups of Iuliu Maniu from 1 September 1940 to the present (probably May 1943), pp. 127-210 (p. 132). 
that Maniu had advised all his party members to support the Legionary government absolutely. ${ }^{120}$

The documentary evidence is contradictory as to whether Sima and Maniu had any direct contact during the period of the National Legionary State. A police report appears to confirm that Sima made contact with Maniu on the evening of 19 September to discuss possible collaboration between the Legionaries and the National Peasant Party. ${ }^{121}$ In the middle of November, however, with the National Legionary regime entering a period of profound crisis, Sima attempted to make contact with Maniu. In response, Maniu apparently exclaimed to his followers that 'Horia Sima had frequent and important meetings with me before the abdication of Carol' but that subsequently Sima had not sought him out or 'shown even the smallest sign of life'. Maniu added that he was willing to meet Sima but that the latter 'was no longer master of the Iron Guard'. ${ }^{122}$

It was indeed increasingly obvious that although Sima had been very skilful in organizing radical elements of the Legion following Codreanu's imprisonment, and at the time of the abdication crisis in September 1940, he was unable to control the increasingly factionalized Legionary movement. Vasile Noveanu and Augustin Bidianu, who had collaborated with Carol earlier in the year, were in conflict with Sima, as was Codreanu's father, Ion Zelea Codreanu. Sima's decisions were constantly contradicted and even the Germans were concerned about his youth (he was 34), his inexperience and lack of authority. Many Romanians apparently regarded him as 'a mere German Gauleiter'. ${ }^{123}$

${ }^{120}$ PA, Inland II geheim: Berichte und Meldungen zur Lage in und über Rumänien: Band 1, bd. 422, 1937-1940: Der Chef des Sicherheitspolizei und SD VI.D3-An./Wi. Berlin, den 15 Oktober 1940 an den Reichsminister des Auswärtigen-Auswärtiges Amt - z.Hd. der Herrn Gesandter Luther: SS-Brigadeführer. When Antonescu was asked by the prosecutor during his post-war trial whether Dinu Brătianu and Maniu were against the Legionaries in 1940, Antonescu replied that 'they were against them, but they did not demonstrate it'. Ciucă, Procesul Mareşalului Antonescu, vol. 3, p. 368.

${ }^{121}$ ANIC, Fond Direcția Generală a Poliției, dosar nr 137/1940, f. 205, Directorate of the security police, 21 September 1940, National Peasantists affirm that Horia Sima has asked Maniu for collaboration between the Legionaries and the National Peasantists.

122 ANIC, Fond Preşedinția Consilului de Miniștri: Cabinet Militar, 1940-1944, dosar $\mathrm{nr}$ 199/1940, 35ff of an unmarked document covering the events of 11 September to 22 November 1940, (ff. 13-15, 15 November 1940). (It is unclear whether any meeting between Maniu and Sima did subsequently take place.)

${ }^{123}$ Argetoianu, vol. 8, Bucharest, 2007, 14 November 1940, pp. 493-94; ANIC, Fond Preşedinția Consilului de Miniştri, Cabinet Militar, 1940-1944, dosar nr 6o/1940, ff. 178-201 (pp. 181-89), Note of 25 October 1940, Comments on the activities of the Legionary movement. 
Moreover, as observed above, by no means all the Legionaries were committed to the pro-Axis foreign policy endorsed by Sima, or to the growth of German influence in the country which followed the arrival of the German military mission to Romania in October 1940. British intelligence observed that 'there are very strong Guardist currents which are anti-German'. ${ }^{124}$ The German take-over of Western economic assets in Romania that autumn even angered the otherwise pro-Axis Sima. ${ }^{125}$ On 23 November, General Antonescu brought the country into the Tripartite Pact whereby Romania officially became an ally of Germany, Italy and Japan. Maniu and Dinu Brătianu made their objections known to Antonescu in a letter. $^{126}$

A major aspect of Maniu's political activity in the autumn of 1940 was connected with the fight to regain northern Transylvania which brought him on a potential collision course with the Reich and with Horia Sima. The organization 'Pro-Transylvania' was founded in Bucharest on 6 October with Maniu as president. Pro-Transylvania sought to mobilize Romanian society in the fight to regain northern Transylvania and to maintain links with the Romanians now under Hungarian sovereignty. The organization also aimed to inform the wider world about the injustices of the Vienna Award through radio broadcasts, meetings and articles. ${ }^{127}$ On 13 November the German-friendly politician, Gheorghe Brătianu, claimed to the German authorities that his role as vice-president of ProTransylvania was the guarantee that the organization would not pursue an anti-German course or oppose the Vienna Award. ${ }^{128}$ Unconvinced by such flagrant contradictions, on 15 November Horia Sima dissolved the association as being incompatible with Romania's international

124 Great Britain, Foreign Office, Weekly Political Intelligence Summaries, vol. 2, nr 53, 9 October 1940. The British Consul in Galați also observed that 'the Iron Guard is essentially anti-German [...] their present alliance is totally unnatural in as much as it is based on an acceptance of a dismemberment of their country'. Correspondence of the British Foreign Office at The National Archives, TNA PRO, FO 371 29990 R142/79/37 (letter from Consul Macrae in Galati [sic] to Mr Scott, 4 November 1940).

125 Haynes, 'Germany and the Establishment of the Romanian National Legionary State', p. 723.

${ }_{126}$ Mihai Pelin (ed.), Mareşal Ion Antonescu. Epistolarul infernului, Bucharest, 1993, doc. 6, pp. 34-6, November 1940, Letter addressed by Constantin I. C. Brătianu and Iuliu Maniu to General Ion Antonescu regarding Romania's adherence to the Tripartite Pact.

127 Andrei Dimitru, 'Pro Transilvania', Magazin istoric, vol. 29, no. 8, 1995, pp. 50-53.

128 PA, Inland II geheim: Berichte und Meldungen zur Lage in und über Rumänien: Band I, Bd. 422, 1937-1940: Der Chef des Sicherheitspolizei und des SD VI. D3-Wa./Wi. Berlin, den 13 November 1940, An des Auswärtige Amt, z. Hd. des Leiters der Abteilung Deutschland Herrn Gesandten Luther. SS-Bridageführer. 
interests. ${ }^{129}$ This did not prevent Maniu sending a memorandum to Hitler and Mussolini on 28 December 1940 protesting once more against the loss of northern Transylvania. ${ }^{130}$

\section{The National Legionary State descends into chaos: Maniu's reaction}

During his trial in 1946, Antonescu described the first month of the National Legionary State as a 'honeymoon' period but that thereafter a power struggle ensued between himself and Sima. ${ }^{131}$ In a letter written to Antonescu in late October 1940, Sima drew attention to the incompatibility of the Legionary regime with the continued existence of the traditional political parties which he demanded be fully suppressed. Sima urged Antonescu to 'lead the country in a Legionary spirit and with the Legionaries.' ${ }^{132}$ Antonescu responded by throwing down the gauntlet to Sima by suggested that he, Antonescu, should become head of both the Legionary movement and government. ${ }^{133}$

On the night of $26 / 27$ November 1940, the Legionaries expressed their hatred of the older generation of politicians and members of the Carolist regime when they murdered sixty-four members of the former royal government at Jilava prison for their involvement in the death of Codreanu and other Legionaries. Later on 27 November, the historian Nicolae Iorga and the National Peasantist economist Virgil Madgearu were also dispatched. Madgearu was found dead in Snagov forest outside Bucharest with six bullets in his head and in his back. ${ }^{134}$ In an interview which took

129 Argetoianu, vol. 8, 21 November 1940, p. 517. Maniu's agreement with the British SOE in September 1940 included the organization of Pro-Transylvania and the related organization, 'Asociația expulzaților şi refugilaților' (Association for Expellees and Refugees). Lazăr, Iuliu Maniu şi serviciilor secrete, pp. 58-63. In December 1940, the British planned to create a pro-Allied organization in Romania based around Maniu and his colleagues and to include 'dissident factions from the original Iron Guard'. Dennis Deletant, British Clandestine Activities in Romania during the Second World War, Basingstoke, 2016, pp. 78-79.

${ }^{130}$ Scurtu, Istoria PNT, pp. 360-61.

${ }_{131}$ Ciucă (ed.), Procesul Mareşalului Antonescu, vol. 3, Bucharest, 1998, p. 362.

${ }_{132}$ ANIC, Fond Președinția Consilului de Miniştri, Cabinet Militar, 1940-1944, dosar nr 158/1940, f. 2, letter from Horia Sima to General Antonescu, Bucharest, 16 October 1940; ibid., dosar nr 6o/1940, ff. 126-29 (p. 129), letter from Horia Sima to General Antonescu, Bucharest, 28 October 1940. (Antonescu had given the National Peasant and National Liberal parties freedom to reorganize their central and county-capital organizations with the proviso that they did not conduct propaganda in the villages which would bring them into conflict with the Legionaries. Argetoianu, vol. 8, 21 November 1940, p. 516.)

${ }^{133}$ ANIC, Fond Președinția Consilului de Miniștri, Cabinet Militar, 1940-1944, dosar nr 6o/1940, ff. 1-6 (f. 4), letter from General Antonescu to Horia Sima, Bucharest, 31 October 1940.

${ }^{134}$ Pe marginea prăpastiei 21-23 ianuarie 1941, 2 vols, Bucharest, 1992, vol. 1, pp. 187-88. 
place in 1961, Horia Sima claimed that the Legionary animosity towards Madgearu was due to his involvement in actions taken against the Legion by the National Peasant Party government of 1928 to 1930. Madgearu was also deemed suspect by the Legionaries because he had intended 'to place the whole of the Romanian economy under the control of international finance.' ${ }^{135}$ The Jilava massacre, the murder of Iorga and Madgearu and the general anarchic atmosphere of the National Legionary State clearly struck terror into the hearts of Romania's traditional politicians. Maniu now feared for his own personal safety. ${ }^{136}$

On 28 November Maniu sent a telegram to the General protesting against the murder of Madgearu. The Manists regarded his murder as entirely unjustified given that Madgearu had been a declared adversary of the Carolist regime and had even been placed under house arrest in March 1940. According to Maniu this was due to his links with the Legionaries, amongst whom was a certain Dr Dorin Haznaş. After Carol's abdication, Madgearu had been in agreement with the National Peasant Party's decision not to oppose the Legionary regime. ${ }^{137}$ Madgearu's funeral was held on 29 November and the presence of many Legionaries created a threatening atmosphere. Maniu bravely took the opportunity to condemn the government for its failure to maintain order and highlighted the chaos created throughout the country by the Legionaries. On 1 December Maniu refused to accompany Antonescu and Sima to the Alba Iulia commemoration of the 1918 union of Transylvania with Romania. ${ }^{138}$ Three days later, Maniu sent a personal letter to Antonescu expressing his fears that the recent spate of political murders were a symptom of impending anarchy which could in turn lead to the country's occupation. ${ }^{139}$

Maniu had further reason to fear for his safety and that of his colleagues. In a letter to Antonescu of 13 December 1940, Maniu drew attention to unfounded accusations against former political leaders made in a radio

${ }^{135}$ Cazul Iorga-Madgearu. Declarații făcute de Dl. Horia Sima revistei 'Carpații', Madrid, 1961, pp. 16-20. It is also likely that the German authorities knew about a plan for Madgearu to speak to SOE representatives in Istanbul and that he was liquidated by Legionaries under Nazi control. Lazăr, Iuliu Maniu şi serviciile secrete, p. 71.

${ }_{136}$ Ciucă (ed.), Procesul Mareşalului Antonescu, vol. 3, pp. 384-85.

137 Cristian Troncotă, Alin Spânu, Florin Pintilie (eds), Documente S.S.I. despre poziția şi activitățile politice din România, 6 septembrie 1940-23 august 1944, 2 vols, Bucharest, 2005-06, vol. 1, 2005, doc. 24, 29 November 1940, pp. 58-59.

${ }_{138}$ Hudiță, Jurnal politic, vol. 2 (7 septembrie $1940-8$ februarie 1941) Iaşi, 200o, Friday 29 November and Sunday 1 December 1940, pp. 144, 152.

139 ANIC, Fond Președinția Consilului de Miniștri: Cabinet Militar, 1940-1944, dosar nr 50/1940, ff. 1-5, Letter from Iuliu Maniu to General Antonescu, Bucharest, 4 December 1940. 
broadcast on 10 December by the Legionary Mille Lefter and subsequently published in the pro-Legionary newspaper Buna Vestire. The broadcast had elaborated upon the persecutions and sacrifices allegedly endured by the Legionary movement's political wing, the Iron Guard (Garda de Fier), between 1930 and 1931. Lefter claimed that Maniu's deputy, Ion Mihalache, had been installed as minister of the interior in January 1931 specifically to dissolve the Iron Guard and the Legion. Maniu denied that Mihalache had been promoted for this purpose and provided examples of Mihalache's interventions against the abuses meted out to the Legionaries by King Carol's regime. Maniu believed that Lefter's speech had been published specifically to stir up public feeling against members of his party. In his letter, Maniu also referred to an inflammatory speech given by Sima to an audience of young people in which he condemned the previous generation of politicians as being oblivious to the crimes of the former royal regime and concerned only with personal enrichment. And this, wrote Maniu in exasperation, was despite the fact that members of the National Peasant Party had been persecuted themselves 'due to our unending attempt to regenerate public life and our resistance to the venal regime of King Carol'. Maniu's letter concluded by alerting Antonescu to the fact that lists of 'condemned' politicians were being circulated by the Legionaries and made a plea for the restoration of the moral order and the principle of equality before the law. ${ }^{140}$

Nevertheless, despite these manifestations of Legionary aggression, Maniu did receive assurances regarding his and Mihalache's safety. In the autumn of 1940 Sima personally pledged to ensure Maniu's security. ${ }^{141}$ In late December, Maniu's nephew, Zaharia Boilă, was received by the

\footnotetext{
${ }^{140}$ Ibid., dosar nr 49/1940, ff. 18-28 (ff. 18, 27), 13 December 1940, Letter from Iuliu Maniu to General Antonescu. Sima relates in his memoirs that Mihalache was disliked by the Legionaries due to his dissolution of the Iron Guard as minister of the interior in January 1931. There was additional conflict in the autumn of 1940 owing to the Legion's take-over of the cooperative movement which Mihalache had established in his home-county of Muscel. Mihalache was also part of the left-wing of the National Peasant Party which, so Sima claims, had Bolshevik links. Horia Sima, Era libertății. Statul Național Legionar, 2 vols, Timişoara, 1995, vol. 1, pp. 251-52. Following the creation of the French Popular Front in 1936, a Romanian Popular Front was established by the Communists, Social Democrats and the left-wing of the National Peasant Party and was led by Mihalache. On 31 May 1936, a demonstration was held in Bucharest presided over by Mihalache. It seems that the sight of Communists with raised fists did not inspire the Romanians and the Front was disbanded shortly after. Veiga, Istoria Gărzii de Fier, pp. 222-23.

${ }^{141}$ Sima informed Mihai Antonescu, the minister for justice, that since Maniu was a Transylvanian and 'a man of quality' no one should be allowed to touch him. Ciucă (ed.), Procesul Mareşalului Antonescu, vol. 3, p. 132.
} 
movement's assistant secretary-general, Victor Boldeanu, at the Legion's administrative headquarters at Str. Gutenberg in Bucharest. Boldeanu assured Boilă that 'serious measures' had been taken to guard the lives of both Maniu and Mihalache. ${ }^{142}$

Many Legionaries were themselves repelled by Legionary violence, as well as being opposed to the German alliance. One such was Dumitru Găzdaru, professor at Iaşi university, who met up with Ioan Hudiță, the National Peasant Party's secretary general for the Regat, on 23 December 1940. Găzdaru expressed his hope that he could convince others in the movement to collaborate with the National Peasant Party and end the German alliance. Hudiță replied that Găzdaru 'could count on our goodwill because we have need of Legionary youth amongst whom very good elements are to be found'. Hudiță concluded that he would 'strive to find a formula for collaboration with all Legionaries who are willing to accept our democratic programme and foreign policy.' ${ }^{143}$

Yet despite these manifestations of Legionary friendship, Maniu had been correct when he informed Antonescu that the Legionaries were preparing a 'black list' of several thousand politicians and democrats for a massacre to take place on New Year's Eve. Fortunately, the military intelligence services (Serviciul Secret de Informații al Armatei Române), now headed up by the anti-Legionary Eugen Cristescu, discovered the plot. Cristescu's appointment as head of military intelligence signified that a show-down between the General and the Legion was imminent. ${ }^{144}$

\section{The January 1941 rebellion and Maniu's response}

Maniu had expected a rupture between the General and the Legion since the autumn of 1940 and he was exceptionally well-informed of events leading up to the January 1941 rebellion. Thus, in a meeting of National Peasant Party leaders held on 10 January 1941, Maniu warned his followers that Legionaries were making military preparations throughout Romania. ${ }^{145}$ Indeed, Maniu appears to have been more abreast with events

142 Zaharia Boilă, Amintiri şi considerații asupra mişcării legionare, Cluj, 2002, pp. $108-15$.

143 Hudiță, Jurnal politic, vol. 2 (7 septembrie 1940 - 8 februarie 1941), Iaşi, 20oo, Monday 23 December 1940, pp. 185-87.

144 Troncotă (ed.), Eugen Cristescu, pp. 62, 152.

145 Hudiță noted that Maniu's principal informants at this time were Alice Sturdza, wife of Mihai Sturdza, the Legionary foreign minister, Prince Nicolae, King Carol's brother who had Legionary connections, and Zaharia Boilă. Hudiță, Jurnal politic, vol. 2 (7 septembrie 1940 - 8 februarie 1941), Iași, 200o, Friday 10 January 1941, pp. 214-16. For Prince Nicolae's links with the Legionaries, see Haynes, 'Reluctant Allies?', p. 113. 
in this regard than many Legionaries. ${ }^{146}$ But although the Legion may have planned to wrest power from the General, events were to provide Antonescu with the opportunity to rid himself of the movement. The murder of a member of the German military mission, Major Doering, on 19 January 1941 enabled Antonescu to discharge both General Petrovicescu, the Legionary minister of the interior, and the head of the Legionary police, Prince Ghyka. On 20 January, however, Legionary students and the militant Legionary Workers' Corps demonstrated in defence of the two discharged Legionaries. On 21 January the workers occupied the telephone and radio stations in Bucharest and three days of bloody street fighting ensued between 21 and 23 January. ${ }^{147}$ The rebellion was eventually put down by the Romanian army, with the assistance of Cristescu's military intelligence services. German tanks, in Bucharest as part of the German military mission, patrolled the streets of Bucharest in a show of support for the General. The rebellion had led to 261 deaths, many of them Jewish, and 377 wounded. ${ }^{148}$

Antonescu received no support from Maniu or Dinu Brătianu during the course of the rebellion, although Maniu subsequently advised the General to form a military government. ${ }^{149}$ Indeed, Maniu had wisely decided to absent himself from Bucharest and lie low during the course of the rebellion. On 18 January, he had advised his close colleagues not to sleep in their homes until the situation had become clear. On Friday 24 January, after the rebellion in Bucharest had been put down, he phoned Ioan Hudiță from Sibiu, informing him that Antonescu was 'irredeemably compromised' through his collaboration with the Legionaries. Antonescu, Maniu believed, should now establish a temporary military government to restore order and then allow King Michael to establish a national government and democratic regime. ${ }^{150}$

${ }^{146}$ For the lack of preparedness for, or even knowledge of, the January 1941 rebellion on the part of many Legionaries, see Clark, Holy Legionary Youth, p. 229.

${ }^{147}$ For an account of the run-up to the rebellion and the events of 21-23 January as recounted by Eugen Cristescu, see Troncotă (ed.), Eugen Cristescu, pp. 187-97. It seems that Major Doering's assassin was a Greek, brought into Romania by two US agents and a British spy. The object of the assassination attempt had in fact been Erik Hansen, head of the German military mission.

${ }^{148}$ Ilarion Țiu, Mişcarea legionară după Corneliu Codreanu, vol. 2: Regimul Antonescu (ianuarie 1941-august 1944), Bucharest, 2007, p. 36.

149 Troncotă (ed.), Eugen Cristescu, doc. 18, pp. 387-93 (p. 391); Ciucă (ed.), Procesul Mareşalului Antonescu, vol. 3, pp. 149-50.

${ }_{150}$ Hudiță, Jurnal politic, vol. 2 (7 septembrie 1940 - 8 februarie 1941), Iaşi, 200o, Saturday 18 January to Friday 24 January 1941, pp. 224-40 (p. 238). 
Antonescu had already taken the decision to dissolve the Legionary regime during the course of the rebellion. ${ }^{151}$ On 27 January 1941 a new government consisting largely of generals and devoid of Legionaries was set up. On 14 February the National Legionary State was formally dissolved. Sima meanwhile escaped arrest following the rebellion and fled into exile in Germany. Together with a small group of senior Legionaries, Sima was taken to Berkenbrück where he came under the jurisdiction of Heinrich Himmler. The Legionaries lived in relative freedom, maintaining contact with some of the Reich's political leaders. The presence of the Legionaries was naturally useful to the Germans as a threat against Antonescu in order to obtain military and economic concessions from him. ${ }^{152}$ Antonescu was to remain under periodic German pressure to incorporate Legionaries into his government. ${ }^{153}$ The National Peasant Party, meanwhile, effectively endorsed Antonescu's crushing of the Legionary rebellion through a series of newspaper articles published between 18 and 27 January 1941 which stressed that the re-establishment of order was the Romanian government's most important priority for the country. ${ }^{154}$

\section{Postscript: Maniu and Horațiu Comaniciu}

Despite the fact that the Legionary movement was legally non-existent after 14 February 1941, its members were past masters at clandestine activity and therefore its organizations continued to function underground in Romania. Romanian Legionaries maintained links with the exiled Command in Germany. ${ }^{155}$ The dissolution of the National Legionary State was by no means, therefore, the end of relations between Maniu and members of the Legion. Indeed, as early as 11 February 1941, Nicolae Petraşcu, Sima's colleague and secretary general of the Legionary movement, announced in a circular that 'the Legion has not died' even though the leadership was going into exile. Petraşcu called on Legionaries left in Romania to resist Antonescu's repression and recommended that they should 'continue to listen to Iuliu Maniu, in the spirit of Codreanu's will of $1938^{\prime}{ }^{156}$ Later that month, a meeting of National Peasant Party leaders met and agreed that

${ }^{151}$ Ciucă (ed.), Procesul Mareşalului Antonescu, vol. 3, pp. 390-91.

152 Dorin Dobrincu, 'Legionarii şi guvernarea Ion Antonescu (1940-1944)', in Kurt Treptow (ed.), Romania: A Crossroads of Europe, 2002, pp. 199-230 (p. 227).

${ }^{153}$ For example, in March 1941, Goering tried to convince Antonescu to bring the Legion back to power. Ciucă (ed.), Procesul Mareşalului Antonescu, vol. 3, p. 403.

${ }^{154}$ Scurtu, Istoria PNT, p. 364. See also, Pelin, Iluziile lui Iuliu Maniu, p. 41.

${ }^{155}$ For the Legion during the Antonescu period and its various factions, both in Romania and in German exile, see Țiu, vol. 2, esp. pp. 44-141.

${ }^{156}$ Ibid., p. 74. 
Antonescu's recent actions were acceptable to them and discussed their joint reaction to Legionary requests to join the National Peasant Party. Such a move was especially popular amongst Transylvanian Legionaries. Maniu declared himself willing to accept Legionaries in the party provided they fulfilled two conditions: unconditional acceptance of the party's democratic programme and a pro-Western foreign policy. ${ }^{157}$ In the spring of 1941, Antonescu's military cabinet noted the intensification of contacts between the National Peasant Party in Transylvania and the Transylvanian Legionaries. ${ }^{158}$

Maniu, together with Zaharia Boilă and Virgil Solomon and other provincial party leaders, remained in communication with members of the Legionary movement following the outbreak of the war against the Soviet Union in $1941 .{ }^{159}$ Maniu was attacked by elements on the left wing of the National Peasant Party for these links, but argued that the dynamism of the Legionaries should be channelled in the direction of revisionism i.e. the return of northern Transylvania. ${ }^{160}$ Indeed, the importance of the Legion's underground organization was underlined by National Liberal Party politicians who reported in the summer of 1942 that 'the only political force to be found on the ground, and which continues to be organized, is that of the Legionaries. ${ }^{161}$

One Legionary who approached Maniu was Horațiu Comaniciu, a lawyer from Miercurea-Ciuc in Transylvania who had been head of the Legionary Ciuc county organization from 1935 to 1937. It is unclear what Comaniciu's position regarding the Carolist regime was during the summer of 1940, but Sima met him shortly after the formation of the National Legionary government. Sima appointed Comaniciu as manager of his vice-presidential cabinet and subsequently made him prefect of Tutova county. ${ }^{162}$

157 Hudiță, Jurnal politic, vol. 3 (9 februarie - 21 junie 1941), Iaşi, 2002, Thursday 20 February 1941, pp. 31-33.

${ }_{158}$ ANIC, Fond Preşedinția Consilului de Miniştri: Cabinet Militar, 1940-1944, dosar nr 248/1940, f. 201, 1 May 1941.

159 Calafeteanu (ed.), Iuliu Maniu - Ion Antonescu. Opinii şi confruntări politice 1940-1944, doc. 20, Report on the activities of the National Peasant groups of Iuliu Maniu from 1 September 1940 to the present (probably May 1943), pp. 127-210 (pp. 140, 205). For a discussion of Maniu's links with Legionaries in the war years, see Mihai Fătu, Antonescu şi Opoziția (1940-1944), Alexandria, 2000, pp. 300-42.

${ }_{160}$ Troncotă et al. (eds), Documente S.S.I. despre poziția şi activitățile politice din România, vol. 1, doc. 155, 9 May 1942, pp. 245-47.

${ }^{161}$ Ibid, doc. 164, pp. 261-62 (262), 8 July 1942.

${ }^{162}$ Horia Sima, Prizonieri ai puterilor Axei, Timişoara, 1995, pp. 140-41. 
Comaniciu first appears to have met Maniu in September 1942. Maniu confirmed that the prerequisite for any future collaboration between the National Peasant Party and the Legionaries was an acceptance of democracy as the foundation of future government together with a foreign policy orientation towards the Western powers. Comaniciu claims in his memoirs that he had already come to regard democracy as more in keeping with the 'Romanian soul' than 'Hitlerism' by 1942 . Comaniciu offered to mobilize the Legionaries for a change of regime and place its youth at the National Peasant Party's disposal. ${ }^{16}$

It was not, however, until 26 August 1944, following the 23 August coup which saw the arrest of Antonescu and the break of diplomatic relations with Germany, that Comaniciu signed a declaration on behalf of the former Legionary Command to the effect that the movement would cease activities. Its members were exhorted to find their place in the new political structure of the country, in any of the parties of the National Democratic Bloc, according to conscience'. Comaniciu explicitly praised Maniu 'who helped us with his advice in our endeavours to find the most appropriate path in new circumstances'. In a letter, Maniu responded that the movement's 'useful energy' should now be channelled into other political groups as conscience and conviction dictated and that 'the doors of the parties of the National Democratic Bloc are open to all'. Comaniciu's declaration and Maniu's reply were subsequently published in the Romanian press. ${ }^{164}$ According to Comaniciu, Maniu had the consent of Britain and the United States to collaborate with the Legionaries. The Romanian authorities even claimed that there were British agents amongst the Legionaries affiliated with Comaniciu. ${ }^{165}$

Being in reality marginal within the movement as a whole meant, however, that Comaniciu was unable to draw the vast majority of

${ }^{163}$ Comaniciu, In lupta neamului, pp. 41, 45-47. During one of their meetings, Maniu apparently showed Comaniciu a letter from the Legionary Senate which confirmed Codreanu's decision that in the event of his death the Legionaries were to follow Maniu. Ibid, p. 294. The Legionary Senate was an advisory body of Legionary sympathisers over the age of 50 .

${ }^{164}$ Scurtu, Istoria PNT, pp. 407-08, with quotes from the party's Dreptatea newspaper of 31 August 1944. The National Democratic Bloc was created in June 1944 with the aim of abolishing the Antonescu dictatorship in favour of a democratic regime, withdrawal from the Axis and the conclusion of an armistice with the Allies. It consisted of the National Peasant and National Liberal parties and the Social Democratic and Communist parties.

165 Comaniciu, In lupta neamului, p. 121; Honciuc-Beldiman (ed.), Dosar Horia Sima, doc. 58, Report by the General Directorate of the State Security Police regarding activities of the Legionaries between 23 August 1944 and 10 December 1945, 10 February 1948, pp. 289-302 (p. 293). 
Legionaries towards the National Peasant Party. ${ }^{166}$ The Communist authorities claimed that at the time of the 23 August 1944 coup, there were some 32,000 Legionaries in Romania, plus 680 in prison and around 300 in exile in Germany. ${ }^{167}$ Of the mere 1,367 Legionaries who joined up to parties of the National Democratic Bloc up to October 1946, the largest number (373) joined the Social Democratic Party, with the second largest number (302) enrolling in the National Peasant Party and 179 in the Romanian Communist Party. The majority of those who entered the National Peasant Party appear to have been codrenişti, who were opposed to Sima, and were believers in taking Maniu's advice in accordance with Codreanu's will and had apparently done so throughout the war. ${ }^{168}$

Comaniciu's writings suggest that Maniu's stress on Christian morality as a basis for public life, as well as his personal probity, were important factors in their collaboration. According to Comaniciu, elements of the movement orientated themselves towards Maniu after Codreanu's death because 'Maniu also wanted to see another democracy, cured of Balkanism [vindecată de balcanisme], grounded in morals'. It seems Maniu now invited Comaniciu and his supporters to help him found a new Christian Social party. ${ }^{169}$

166 As Sima points out, Comaniciu was unable to speak on behalf of the movement as a whole since he had never occupied a role of the first rank within the Legion. Sima, Prizonieri ai puterilor Axei, p. 140.

167 Troncotă et al. (eds), Documente S.S.I. despre poziția şi activitățile grupurilor politice din România, 6 septembrie 1940-23 august 1944, vol. 2, 2006, doc. 173, 11 March 1944, p. 320; Honciuc-Beldiman (ed.), Dosar Horia Sima, doc. 58, Report by the General Directorate of the State Security Police regarding activities of the Legionaries between 23 August 1944 and 10 December 1945, 10 February 1948, pp. 289-302 (p. 289).

168 Constantin Petculescu, Mişcarea Legionară: mit şi realitate, Bucharest, 1997, pp. 230-31. The authorities confirmed that those who followed Maniu after 23 August were 'adversaries of the simist leadership' and of terrorism. Honciuc-Beldiman (ed.), Dosar Horia Sima, doc. 47, Informative note of the Intelligence Service regarding differences between the Legionary movement in the country and Legionary groups in Germany and Austria, 15 April 1946, pp. 275-79 (p. 278). See also, a ministry of the interior report from early 1943 that, as the tide of war began turn to against the Germans with their defeat at the Battle of Stalingrad, certain codrenişti Legionaries sought to strengthen their links with the pro-Western Manists in order to save their faction of the movement: ANIC, Fond Ministerul de Interne, Diverse, dosar nr 35/1935 [sic], f. 331, Linia 1F, 14 January 1943.

${ }^{169}$ H. Comăniciu [sic], 'Iuliu Maniu şi Mişcarea Legionară, Vatra (Freiburg), no. 152, October-December 1979, pp. 5-9 (p. 7). My thanks to my postgraduate student, Liviu Iacob, for acquiring a copy of this article for me. The two books which Maniu kept on his desk were a copy of the train timetable and the Holy Bible. For the 'Christian democratic' elements of Maniu's political thinking, see Dorin Constantin Domuța, 'Premisses démocrates chrétiennes à la pensées politique de Iuliu Maniu', Studia Universitatis BabeşBolyai. Studia Europaea, 48, 2003, 1, pp. 55-62. 
Maniu clearly took considerable risks in defending the Legionaries in the climate of growing Communist strength, especially when the leader of the Communist Party, Gheorghiu Gheorghiu-Dej, began calling for the liquidation of the Legionary movement. ${ }^{170}$ On 24 October 1944, when the Communists were purging all government workers who had not belonged to the National Democratic Bloc on 23 August, Maniu made a declaration to the press and radio. Maniu stressed the decision taken by Comaniciu in 1942 that the Legionary movement should take the democratic path. ${ }^{171}$ In the autumn of 1944, Comaniciu, fearing that the authorities intended to massacre the Legionaries, sought out Maniu for protection. Maniu made a crucial phone call to intervene for the Legionaries, apparently appealing to his interlocutor with the phrase, "They [the Legionaries] are our Romanians; we cannot abandon them. ${ }^{172}$ Maniu also attempted to protect the Legionary and priest, Ion Dumitrescu-Borşa, in the autumn of 1944 on the basis that Borşa would be persecuted by the Communists because of his involvement in the Spanish Civil War on the nationalist side. ${ }^{173}$

It seems there were even secret discussions between Maniu and Sima's deputy, Nicolae Petraşcu, who was parachuted into Romania in November 1944, to set up a new Legionary Command. Over the following year, Petraşcu established seventeen organizations and centres of resistance against the Soviet occupation. ${ }^{174}$ Maniu was clearly reserved towards this approach from the Sima-wing of the movement, suggesting only that the movement legalize its status with the government. The fall of Nazi Germany in May 1945 and the Romanian government's subsequent arrest of Legionaries, led Petraşcu to come to an agreement with the Communist authorities, which granted the Legionaries an amnesty in December 1945 provided they did not join the National Peasant or National Liberal parties or oppose the Communist Party. This did not, however, prevent Petraşcu from sending an emissary to Maniu informing him that the Legion

170 Scurtu, Istoria PNT, p. 408.

${ }^{171}$ Comaniciu, In lupta neamului, p. 119.

${ }^{172}$ Comăniciu, 'Iuliu Maniu şi Mişcarea Legionară', p. 9. For Comaniciu’s comment that Maniu had a 'parental concern' for the Legionaries, see Haynes, 'Reluctant Allies?', p. 133.

173 For Dumitrescu-Borşa's account of his meeting with Maniu, see Preot Ion Dumitescu-Borşa, Cal Troian intra muros: memorii legionare, Bucharest, no date, pp. 40510. Dumitescu-Borşa had been secretary of the movement's political wing, 'Totul pentru Țară'. In November 1940 he was excluded from the movement by Sima. He was part of the codrenişti wing of the movement during the war, together with Codreanu's sister, Iridenta, and Codreanu's wife, Elena. Dorin Dobrincu, 'Legionarii şi guvernarea Ion Antonescu (1941-1944)', p. 216.

${ }^{174}$ For the following overview of the fate of the Legionary movement from 1944 to 1948 , see Petculescu, Mişcarea Legionară, pp. 227-44. 
remained true to him and that 'when the time comes to fight, the Legion will be present. ${ }^{175}$

Members of the Legionary movement subsequently entered the antiSoviet, national resistance movement led by General Aurel Aldea. One of the many groups (although by no means the most significant) within the anti-Soviet resistance, was 'Haiducii lui Avram Iancu' (lit. The Bandits of Avram Iancu. The latter had led the Romanians in the 1848 revolution in Transylvania). This had been formed from the remnants of the National Peasant Party's paramilitary organization, 'Iuliu Maniu', which had been dissolved by the authorities in November 1944 but was subsequently led by Legionaries as part of the resistance movement. ${ }^{176}$ In 1947 , however, the historic parties and the Romanian monarchy were abolished. Maniu was tried and sentenced to life imprisonment in November. In the following year the Communists began the mass arrest of Legionaries. Maniu, the National Peasant Party and the Legionary movement finally disappeared from Romanian public life.

\section{Conclusion}

It would be simplistic to argue that Maniu's collaboration with the Legion was consistently with the codrenişti wing of the movement. The simişti/codrenişti split was not always clear cut at the time. As we have seen, Comaniciu, who identified himself with the codrenişti wing of the movement in his memoirs, accepted posts from Sima during the period of the Legionary government in 1940. Nevertheless, those who sought collaboration with Maniu in 1944 were from the codrenişti wing whose members now eschewed the leadership of Sima. ${ }^{177}$

Following Codreanu's murder, Maniu had expected Sima to stand firmly by Codreanu's will and consult him on an on-going basis and was disappointed that Sima did not do so. Nevertheless, at certain points

${ }^{175}$ Quoted in ibid., p. 235.

176 For the creation of paramilitary units by both the National Liberal Party and the National Peasant Party in 1935, see Hans-Christian Maner, Parlamentarismus in Rumänien (1930-1940). Demokratie im autoritärien Umfeld, Munich, 1997, pp. 231-32.

177 Maniu appears to have retained a regard for Codreanu. According to the Legionary Alexandru Serafim, in 1945 Codreanu's mother visited Maniu and asked him to intervene with the authorities for the release from prison of her daughter, Iridenta Moța, and her daughter-in-law, Elena Codreanu. Maniu allegedly replied that 'I can do nothing. I myself expect to be arrested. Madame, I have not had children, but if I had I would have wanted them to be like your son Corneliu!'. Alexandru Serafim, 'Iuliu Maniu despre Corneliu Codreanu', in Gabriel Stănescu (ed.), Iosif Toma Popescu. Memorial Iuliu Maniu, Bucharest, 2006, pp. 141-42. 
the lines of communication were open between the two men through Horia Cosmovici, Ion Nicolau and Nicolae Petraşcu. Occasionally, Maniu possibly even had direct contact with Sima, as appears to have been the case in the period leading up to Carol's abdication in September 1940. Maniu had condemned the antisemitism and the use of violence in his meetings with the Legionaries in the late 1930s, and was clearly appalled by the Legionary terror which marked the National Legionary State. He was ready to support Antonescu up until 1944 and endorse a military regime rather than countenance a return to any form of Legionary government following the General's dissolution of the movement in February 1941.

What he thought of Horia Sima personally is unclear. He is reputed to have said in October 1940 'up to the present moment, Horia Sima has shown much political ability, establishing himself as a political personality of the first rank'. ${ }^{178}$ But given that this quotation was brought up by Maniu's prosecutors at his trial in 1947 , it is not clear whether it can be taken seriously. Even if Maniu did make this comment, the date is significant. In October 1940, the Legion under Sima was still at the height of its power and only a brave but foolish man would have openly condemned Sima. Moreover, it is important to bear in mind that Maniu, ever the diplomat, maintained good links with friend and foe alike throughout the war. ${ }^{179}$

Not every National Peasant Party leader agreed with Maniu's policy of maintaining links with the Legion. Both Ion Mihalache and Virgil Madgearu, amongst others, had advised against this, although, as we have seen, both men ultimately had connections with individual Legionaries or had sought at times to protect the movement from the worst excesses of the Carolist regime. ${ }^{180}$ A contemporary historian has also condemned Maniu for his support for the Legion, especially for allowing them to infiltrate the post-war resistance movement. ${ }^{181}$ The Legion's strong organization and relative popularity and influence in Romania, however, made it difficult to ignore. Had Maniu done so, there was the risk that the movement might have become the tool of anti-democratic forces. Moreover, the fact that many Legionaries rejected Sima's pro-Axis position provided a natural

${ }_{178}$ Ciucă (ed.), Procesul lui Iuliu Maniu, vol.1, doc. 18, pp. 95-112 (p. 98).

179 For Maniu's links with the Communists during the war, see Cristian Troncotă's introductory study to vol. 2, Troncotă et al. (eds), Document S.S.I. despre poziția şi activitățile grupurilor politice din România, pp. 25-46 (pp. 41-45).

${ }^{180}$ On the hostility of certain elements of the National Peasant Party towards the 1937 electoral non-aggression pact with the Legion, see Haynes, 'Reluctant Allies?', pp. 118-19. See Petculescu, Mişcarea Legionară, pp. 233-34 for the National Peasant Party leaders who opposed bringing Legionaries into the party after the war.

${ }^{181}$ Ibid., p. 238. 
point of contact between Manists and Legionaries for the defence of Transylvania.

The Communists were, therefore, correct in their accusation at his trial that Maniu and the National Peasant Party had sustained links with the Legionaries going back into the 1930s. The Communists were, however, wrong in claiming that Maniu had forged these relations because of fascist and Hitlerite sympathies. Maniu remained pro-Western and committed to democracy throughout the period of his contacts with the Legion. Indeed, it was the Legion which was expected to adapt its ideology to his. As a result, there is clear evidence of some convergence of views between Maniu and certain elements of the movement by 1944, which might have led to a new form of politics in the form of Christian Socialism, or a Romanian brand of the Christian Democracy which was to emerge elsewhere in postwar Europe. This experiment was, however, cut short by the imposition of Communism.

It is worth bearing in mind, however, that relatively few Legionaries out of many thousands joined the National Peasant Party after the war. Despite the frequent statements by the Manists regarding enrolling Legionaries in the party from the late 1930s onwards, it is unclear how many officially joined the party before 1944. It is not even certain whether Comaniciu himself became an official party member. ${ }^{182}$

It says much for Maniu's personal integrity that he did not attempt to hide his links with the Legionaries following his arrest, unlike his former National Peasant Party colleague, Alexandru Vaida-Voevod. In the early 1930 S Vaida-Voevod had regarded himself as the 'Godfather' of the Legionary movement, to which he had donated some 20,00o pairs of boots. Yet he claimed in his post-war memoirs that he had found the Legion 'childish'. Vaida-Voevod further argued that, as a clear precursor to 'Hitlerism', King Carol had been entirely justified in destroying the Legionary movement. Many pages of his memoirs are thus dedicated to denying the strength of his links with the Legion. ${ }^{183}$

${ }^{182}$ During his trial, Maniu stated that Comanicu was not a member of the National Peasant Party. Ciucă (ed.), Procesul lui Iuliu Maniu, vol. 2, part 2, Bucharest, 2001, doc. 84, pp. 90-92 (p. 91). It was not unknown for the reverse process to take place, i.e. those with National Peasant Party affiliations to join the Legion. Ion Mihalache, giving evidence at Maniu's trial, stated that the senior Legionary and Spanish Civil War hero, Vasile Marin, had at one point been secretary of Maniu's office before leaving the National Peasant Party for the Legion. Ibid., vol. 1, doc. 53, pp. 199-229 (p. 200). On this point see also, DumitescuBorşa, Cal Troian intra muros, p. 92.

${ }^{183}$ Alexandru Şerban (ed.), Alexandru Vaida-Voevod. Memorii, 4 vols, Cluj, 1994-98, see esp. vol. 3, 1997, pp. 162-79. For the 20,000 pairs of boots, see Hungarian National 
Maniu's testimony during Antonescu's trial, on the other hand, shows that he was prepared to see the merits of individual Legionaries despite the collective violence of the movement. On being asked by the prosecution whether he realized that the Legion was a Fifth column for Germany, he replied that he could not confirm this as he was unclear whether the question referred to the whole of the movement or only to specific persons within it. Maniu added that he 'had found members of the Iron Guard to be very patriotic, honest and well-intentioned'. He added that 'proof of this could be found in the fact that the ruling Communist Party had itself seen fit to accept many former Legionaries into the party. This comment led to considerable hubbub within the court-room [Gălăgie în sală] ${ }^{184}$

Archives, Budapest, Department K, 63, 240, 27/1, 22 November 1933. My thanks to Dr Thomas Lorman for providing this reference.

${ }^{184}$ Ciucă (ed.), Procesul Mareșalului Antonescu, vol. 2, p. 67. It should also be recalled that the Communist Party told its members to vote for Maniu in the 1937 election despite his non-aggression pact with the Legion. Haynes, 'Reluctant Allies?', p. 118. 